\title{
Pistacia Genus as a Potential Source of Neuroprotective Natural Products
}

Authors

Reihaneh Moeini ${ }^{1,2}$, Zahra Memariani ${ }^{1,2}$, Farideh Asadi ${ }^{3}$, Mahbubeh Bozorgi ${ }^{4}$, Narjes Gorji ${ }^{1,2}$

Affiliations

1 Traditional Medicine and History of Medical Sciences Research Center, Health Research Institute, Babol University of Medical Sciences, Babol, Iran

2 Department of Persian Medicine, School of Persian Medicine, Babol University of Medical Sciences, Babol, Iran

3 Department of Pharmacology and Toxicology, Faculty of Pharmacy, Tehran University of Medical Sciences, Tehran, Iran

4 Persian Medicine and Pharmacy Research Center, Tehran University of Medical Sciences, Tehran, Iran

Key words

Alzheimer, flavonoids, neurodegenerative diseases, Pistacia, phenolic compounds, terpenes

received March 31, 2019

revised September 14, 2019

accepted September 16, 2019

Bibliography

DOI https://doi.org/10.1055/a-1014-1075

Published online October 11, 2019 | Planta Med 2019; 85:

1326-1350 @ Georg Thieme Verlag KG Stuttgart · New York I ISSN 0032-0943

Correspondence

Zahra Memariani, Pharm D, PhD

Department of Traditional Persian Medicine, Faculty of

Traditional Persian Medicine, Babol University of Medical

Sciences

P. O. Box, 4717647745 Babol, I. R. Iran

Phone: + 989128239567 , Fax: + 981132190181

z.memariani@mubabol.ac.ir

\section{ABSTRACT}

Neuroprotective agents are able to defend the central nervous system against acute or chronic neuronal injuries. Even with the progress made over the last decades, most of the medications prescribed for the management of neurodegenerative diseases can only reduce their symptoms and slow down their progression. Based on natural product research, there are potential effective medicinal plants and phytochemicals for modulating neuronal functions and protecting against neurodegeneration. Plants in the genus Pistacia are also among valuable natural resources for neuroprotection research based on experiences in traditional medicine. Studies have supported the value of bioactive compounds of the genus Pistacia for central nervous system disorders such as Alzheimer's, Parkinson's, multiple sclerosis, cerebral ischemia, depression, and anxiety. Related literature has also revealed that most of the evidence on neuroprotection in the genus Pistacia is in the form of preliminary studies, mainly including models of behavior, motor function, and memory impairments in animals, neural toxicity, cerebral ischemia and seizure models, evaluation of their effects on antioxidant and inflammatory biomarkers, amyloid $\beta$ aggregation, and acetylcholinesterase as well as investigations into some cellular pathways. Along with the phytonutrients in kernels such as pistachios, various phytochemicals, mostly terpenes, and phenolic compounds have also been identified in different plant parts, in particular their oleoresins, of species in the genus Pistacia. In this review, the pharmacology of neurological effects and related molecular mechanisms of the plants belonging to the genus Pistacia and its active constituents, as well as pharmacokinetics aspects, are discussed.

\section{Introduction}

As one of the remarkable modalities of complementary medicine, natural products create a potential platform for drug discovery and development, especially for chronic diseases and major health problems associated with aging. Concentrating on neuroprotective activity of natural products to control or prevent neurodegenerative diseases (NDs) is relatively a new research area [1]. It should be noted that neuroprotective agents are able to defend the CNS against acute (e.g., stroke or trauma) or chronic (e.g.,
$A D$ and $P D$ ) neuronal injuries [2] resulting from the breakdown and deterioration of neurons [3]. Despite differences in anatomic distribution of NDs, leading to various manifestations, it seems that their pathologies have numerous similarities at subcellular levels [4]. In this respect, aggregation of proteins, inflammation, oxidative stress, as well as loss of neurotransmitters are considered among common pathologies of NDs [3]. Even with the progress made over the last decades, most of the clinically prescribed medications for the management of NDs can merely reduce ND 


\begin{tabular}{|c|c|}
\hline \multicolumn{2}{|c|}{ ABBREVIATIONS } \\
\hline 6-OHDA & 6-hydroxydopamine \\
\hline ABTS & $\begin{array}{l}\text { 2,2'-azino-bis(3-ethylbenzothiazoline-6- } \\
\text { sulphonic acid }\end{array}$ \\
\hline AD & Alzheimer's disease \\
\hline BDNF & brain-derived neurotrophic factor \\
\hline CAT & catalase \\
\hline CNS & central nervous system \\
\hline COX-2 & cyclooxygenase-2 \\
\hline DCF-DA & $2^{\prime}, 7^{\prime}$-dichlorofluorescin diacetate \\
\hline DPPH & 2,2-diphenyl-1-picrylhydrazyl \\
\hline GABA & gamma-aminobutyric acid \\
\hline GPx & glutathione peroxidase \\
\hline IL & interleukin \\
\hline NF- $k B$ & $\begin{array}{l}\text { nuclear factor kappa-light-chain-enhancer of } \\
\text { activated B cells }\end{array}$ \\
\hline NO & nitric oxide \\
\hline Nrf2 & nuclear erythroid 2-related factor 2 \\
\hline PC12 & pheochromocytoma cells \\
\hline PD & Parkinson's disease \\
\hline PPAR & peroxisome proliferator-activated receptor \\
\hline PTZ & pentylenetetrazole \\
\hline SOD & superoxide dismutase \\
\hline TBARS & thiobarbituric acid reactive substances \\
\hline
\end{tabular}

symptoms and slow down their progression, and, conversely, lead to unavoidable adverse effects [5].

In recent years, plant-based products have received considerable attention. Hence, there is a strong tendency towards research on phytochemicals for modulating neuronal functions and protecting against neurodegeneration [6]. Numerous medicinal plants have also been recommended for the prevention and treatment of various diseases of the CNS in traditional medicine across the world [7]. Many of these herbs have been extensively studied regarding their neuroprotective effects. In addition, they have been reported to modulate multiple signal transduction pathways through direct effects on enzymes such as kinases, regulatory proteins, and receptors [8]. Panax ginseng C. A. Mey., Ginkgo biloba L., Curcuma longa L. and Bacopa monnieri (L.) Pennell. are among the most prominent plants examined in this field [7]. Plants in the genus Pistacia, belonging to the family Anacardiaceae [9], are also considered one of the valuable natural resources for neuroprotection research based on experiences in traditional medicine. This genus consists of at least 10 species in which Pistacia vera L., Pistacia lentiscus L., Pistacia terebinthus L., Pistacia atlantica Desf., and Pistacia integerrima J.L. Stewart ex Brandis. [Pistacia chinensis subsp. integerrima (J. L. Stewart ex Brandis) Rech. f.] are regarded as the most known ones. Among them, pistachios are more widely known because of the edible nature of their seeds. Although some others may also be suitable for eating, they are most often recognized for their oleoresin with industrial, pharmaceutical, and cosmetic uses [10]. In this study, along with elucidating traditional usage and evidence related to neuroprotective effects of these herbs, their major active ingredients and possible mechanisms of action as well as pharmacokinetic aspects were reviewed.

\section{Traditional Medicinal Usage of the Pistacia Genus}

Hippocrates, Dioscorides, and Galen reported the distinctive characteristics of mastic gum (P. lentiscus oleoresin), such as taste and odor as well as therapeutic properties. Based on historical documents, this substance was the first natural chewing gum of the ancient world of Europe that was used to clean the teeth and to freshen the breath [11]. P. lentiscus has traditionally been used for memory improvement, as well as the treatment of stomachache, burn skin, asthma, and bronchitis in Algeria [12]. Even though the most important use of this oleoresin was the treatment of digestive problems such as gastric pains, it was introduced as a brain booster and protector in Greek and Persian traditional medicines, both having the same roots according to historical references. Its oleoresin, especially with olibanum, has also been prescribed orally for this purpose, especially for memory improvement. It has similarly been recommended for treating some types of headaches, psychiatric disorders, and management of stroke [13]. Leaves of the plant are traditionally used for toothaches, mycosis, herpes, abdominal and intestinal pain, rheumatism, antiseptic, cicatrizant, and as an astringent in Italy $[14,15]$. The fruits have been used in Tunisia as a condiment and also for the treatment of scabies, rheumatism, and diarrhea [16].

Most therapeutic applications and reported uses of $P$. atlantica are related to traditional Persian medicine since the western region of Iran is one of the largest centers for producing this species, and its oleoresin is being used as chewing gum [17]. This oleoresin has therapeutic uses similar to mastic gum according to the written documents in traditional Persian medicine $[18,19]$. In fact, in these documents, it has been prescribed to strengthen the stomach and the teeth, and also to cleanse the brain from waste materials interfering with brain activity such as memory. Its processed trunk exudate is used to clear mouth, gum, and teeth diseases, improving memory, and reducing stress [20]. In the western regions of Iran, the fruit of this plant, named bane, is also used as a nut, usually after grinding [21].

Records of the consumption of fruits of $P$. vera (pistachio) as a food date back to 7000 BC. Now it is cultivated in the Middle East, especially in Iran and Mediterranean countries as well as Turkey and the United States [22]. The oleoresin is used in folkloric medicine as chewing gum in Europe and the Middle East. In India, pistachios have been reported as a remedy for liver disorders, abscesses, and poor circulation [23]. In Turkey, pistachio gum has been used as a treatment for asthma, stomachaches, and hemorrhoids [24]. The fruits and fruit kernel of $P$. vera are used for strengthening the liver, heart, and stomach and as a brain tonic in traditional Persian medicine, as well [18]. In some areas of Jordan, the oil of the fruit has been used as a facial skin cleanser [25]. $P$. integerrima ( $P$. chinensis subsp. integerrima) is known as kakra shingi in India. Its gall is currently being utilized to treat hepatitis and liver problems in Pakistan [26]. It is also known as an aromatic, astringent, expectorant, sedative, and spasmolytic agent in Ayurveda, and is being employed to treat asthma and chronic bronchitis, dysentery, and fever, as well as skin diseases [27]. The fruit of $P$. terebinthus has been recommended for the treatment of 


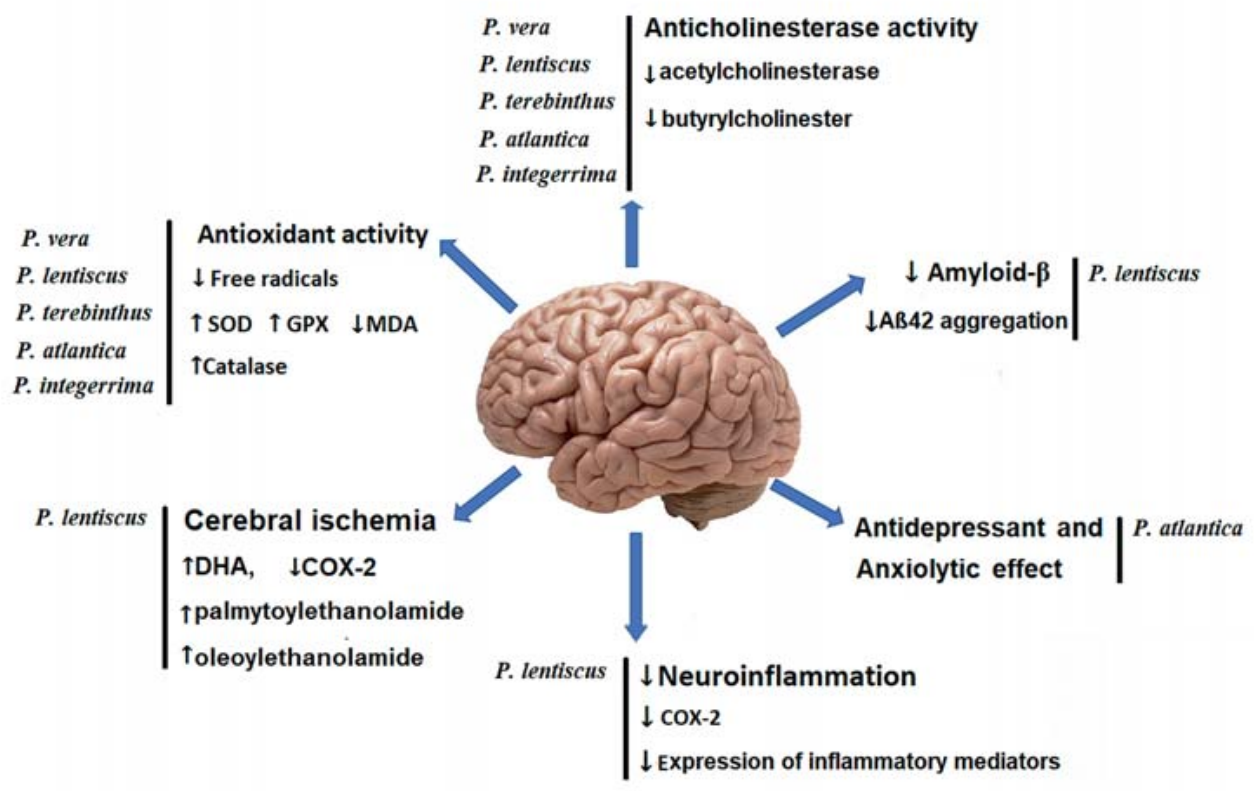

- Fig. 1 Pharmacological aspects of the Pistacia genus on the brain.

colds, flu, stomachaches, rheumatism, and urinary inflammations. It has also been used as a diuretic, stimulant, antitussive, and appetizer, and as coffee in Turkey [28-30].

\section{Evidence Related to the Neuroprotection in the Pistacia Genus}

\section{Search strategy}

To obtain articles that directly assessed the neuroprotective activity of the plants in the Pistacia genus, databases including Scopus, PubMed, and Google Scholar were searched from 2000 to February 2019. Key words included "brain”, “memory”, “neuron”, "nootropic" "neuroprotective”, "neurodegenerative”, “cognition”, “dementia”, “Alzheimer”, "Parkinson”, “amyotrophic lateral sclerosis", "stroke”, “seizure”, "anxiety”, and "depression” along with the word "Pistacia" and also with each full scientific name of the plants. All studies that were in English and had full text were selected. The strategy was run by two researchers and then the findings of both were combined and duplicates were deleted. Obtained studies are classified in $\mathbf{r}$ Table 1 regarding the details of each study, including plant part, type of study, dose, duration, and results.

Most of the evidence related to neuroprotection activity in the genus Pistacia is in the form of preliminary in vitro/vivo studies; mainly including models of memory, motor function, and behavioral impairments in animals, neural toxicity, cerebral ischemia, and seizure models, evaluation of their effects on antioxidant and inflammatory biomarkers, amyloid- $\beta(\mathrm{A} \beta)$ aggregation, acetylcholinesterase (AChE), as well as investigations into some cellular pathways ( $\triangleright$ Figs. 1 and 2 ).
Even with the widespread presence of pistachios as the most commonly used phytonutrient-dense species of this genus, no clinical studies have directly aimed at investigating their effects on neurodegenerative disorders. In the following, studies on the neuroprotective effects of each individual plant are presented.

\section{Pistacia vera}

In this domain, most of the studies have been carried out on pistachio's kernel, hull, and its gum (oleoresin). In this respect, the neuroprotective effects of $P$. vera kernel was specified in a study through its administration for 5 weeks in rats, which could inhibit cognitive and motor impairments caused by cisplatin or vincristine and specifically reverse spatial memory disturbances by these neurotoxic anticancer drugs. However, pistachio has not indicated any effects on anxiety as monitored by the open field test. Its cognitive improvement effects might have been also related to high flavonoids and phenolic content of the pistachio fruit [31]. P. vera seed oil has been further reported to improve memory and cognitive impairment, as suggested by $\mathrm{Y}$-maze test results in rats. However, it has not revealed any effects on spatial memory parameters in the Morris water maze test [32]. Moreover, one study found that the hydroalcoholic extract of pistachio nut (orally; 14 days) had significantly caused improved learning and memory in rats through the avoidance learning test [33]. In parallel, the aqueousmethanolic extract of $P$. Vera hull has been able to inhibit AChE activity to a certain extent. In this case, the $I_{50}$ of $204.1 \pm 6.33 \mu \mathrm{g} /$ $\mathrm{mL}$ was compared with physostigmine $\left(\mathrm{IC}_{50}\right.$ of $\left.0.093 \mu \mathrm{M}\right)$ [34]. Moreover, the AChE inhibitory activity of its fruit hull methanol extract was proven in another study by a percentage of $5.5 \%$ in enzyme inhibition [35]. The anxiolytic effect of the hydroalcoholic extract of its hull $(10 \mathrm{mg} / \mathrm{kg})$ has been shown in female rats, which 
- Table 1 Pharmacological evidence related to the neuroprotection in the Pistacia genus.

\begin{tabular}{|c|c|c|c|c|c|c|c|c|}
\hline $\begin{array}{l}\text { Scien- } \\
\text { tific } \\
\text { name }\end{array}$ & $\begin{array}{l}\text { Plant } \\
\text { part }\end{array}$ & $\begin{array}{l}\text { Extract/essen- } \\
\text { tial oil/active } \\
\text { compound }\end{array}$ & $\begin{array}{l}\text { In vivol } \\
\text { in vitro }\end{array}$ & $\begin{array}{l}\text { Animal } \\
\text { species }\end{array}$ & Dose/duration & Assay/method/model & Results & Ref \\
\hline \multirow[t]{11}{*}{ P. vera } & Hull & $\begin{array}{l}\text { Aqueous- } \\
\text { methanolic } \\
\text { extract }\end{array}$ & In vitro & - & $100 \mu \mathrm{g} / \mathrm{mL}$ & AChE inhibitory assay. & AChE inhibitory activity & [34] \\
\hline & Kernel & Oil & In vivo & Male rats & $\begin{array}{l}1 \text { and } 4 \mathrm{~mL} / \mathrm{kg} \text {; } \\
\text { p. o.; } 21 \text { days }\end{array}$ & $\begin{array}{l}\text { Morris water maze (MWM) } \\
\text { and Y-CAT maze. }\end{array}$ & $\begin{array}{l}\text { Improved memory performance } \\
\text { in Y-CAT maze test. } \\
\text { The extract did not affect } \\
\text { spatial learning and memory } \\
\text { parameters in MWM. }\end{array}$ & [32] \\
\hline & $\begin{array}{l}\text { Oleo- } \\
\text { resin }\end{array}$ & $\begin{array}{l}\text { Hydroalcoholic } \\
\text { extract }\end{array}$ & In vivo & Mice & $\begin{array}{l}0.25,0.5 \text {, and } \\
1 \mathrm{~g} / \mathrm{kg} ; \mathrm{i} . \mathrm{p} \text {. }\end{array}$ & $\begin{array}{l}\text { Pentobarbital model of sleep } \\
\text { induction. } \\
\text { Traction and rotarod tests. } \\
\text { Elevated plus maze and open } \\
\text { field tests. }\end{array}$ & $\begin{array}{l}\text { Hypnotic, antianxiety, and } \\
\text { muscle relaxant activities. }\end{array}$ & [40] \\
\hline & Fruits & $\begin{array}{l}\text { Pistachio sus- } \\
\text { pension }\end{array}$ & In vivo & Male rats & $\begin{array}{l}10 \% \text { dietary } \\
\text { pistachio daily; } \\
5 \text { weeks }\end{array}$ & $\begin{array}{l}\text { Model of motor and cognition } \\
\text { impairments induced by } \\
\text { cisplatin or vincristine. } \\
\text { Rotarod and grasping tests; } \\
\text { open field test. } \\
\text { MWM }\end{array}$ & $\begin{array}{l}\downarrow \text { Some learning, memory, } \\
\text { and motor impairments. }\end{array}$ & [31] \\
\hline & Hull & $\begin{array}{l}\text { Methanolic } \\
\text { extract }\end{array}$ & In vitro & - & - & AChE inhibitory assay. & AChE inhibitory activity. & [35] \\
\hline & Kernel & $\begin{array}{l}\text { Hydroalcoholic } \\
\text { extract }\end{array}$ & In vivo & Rats & $\begin{array}{l}10,50, \text { and } \\
100 \mathrm{mg} / \mathrm{kg} / \text { day; } \\
\text { p. o.; } 14 \text { days }\end{array}$ & $\begin{array}{l}\text { Avoidance learning test using } \\
\text { the shuttle box. }\end{array}$ & $\begin{array}{l}\uparrow \text { The latency to enter the dark } \\
\text { room. } \\
\downarrow \text { Time spent in the dark room } \\
\text { improved learning and memory. }\end{array}$ & [33] \\
\hline & Leaves & $\begin{array}{l}\text { Aqueous and } \\
\text { ethanolic } \\
\text { extracts }\end{array}$ & In vivo & Mice & $\begin{array}{l}0.4 \mathrm{~g} / \mathrm{kg} \text { and } \\
0.5 \mathrm{~g} / \mathrm{kg} ; \text { i. p. }\end{array}$ & $\begin{array}{l}\text { Hot plate and writhing tests. } \\
\text { Xylene-induced ear edema. } \\
\text { The cotton pellet test. }\end{array}$ & Antinociceptive. & [194] \\
\hline & $\begin{array}{l}\text { Ripe pis- } \\
\text { tachio } \\
\text { hulls }\end{array}$ & $\begin{array}{l}\text { Hydroalcoholic } \\
\text { extract }\end{array}$ & In vivo & $\begin{array}{l}\text { Female } \\
\text { Wistar } \\
\text { rats }\end{array}$ & $\begin{array}{l}\text { Single dose of } 0.1 \text {, } \\
1,10,50,100 \text {, } \\
250,500 \mathrm{mg} / \mathrm{kg} \text {; } \\
\text { i. p. }\end{array}$ & $\begin{array}{l}\text { Elevated plus maze model of } \\
\text { anxiety. }\end{array}$ & $\begin{array}{l}\text { Percentage of time spent in the } \\
\text { open arms (\%OAT), percentage } \\
\text { of the number of entries into the } \\
\text { open arms (\%OAE). }\end{array}$ & [36] \\
\hline & Seed & Hexan extract & In vitro & - & $\begin{array}{l}\text { PC12 cells were } \\
\text { pretreated with } \\
\text { extract for } 48 \mathrm{~h} \\
(10 \%, v / v)\end{array}$ & $\begin{array}{l}\text { Measurement of intracellular } \\
\text { oxidative stress. } \\
\text { DPPH assay with Trolox. } \\
\text { Measurement of cell viability } \\
\text { by the MTT reduction assay. }\end{array}$ & $\begin{array}{l}\uparrow \text { Cell viability. } \\
\downarrow \text { Intracellular ROS. }\end{array}$ & [37] \\
\hline & Kernel & $\begin{array}{l}\text { Hydroalcoholic } \\
\text { extract }\end{array}$ & In vivo & Male rats & $\begin{array}{l}50 \text { and } \\
100 \mathrm{mg} / \mathrm{kg} \text {, } \\
\text { p. } 0 . ; \text { every day } \\
\text { ( } 30 \text { days) }\end{array}$ & $\begin{array}{l}\text { Convulsive model induced by } \\
\text { PTZ injection. }\end{array}$ & $\begin{array}{l}\downarrow \text { Seizure scores, stage } 4 \text { latency } \\
\text { and stage } 5 \text { duration. }\end{array}$ & [41] \\
\hline & Gum & $\begin{array}{l}\text { Hydroalcoholic } \\
\text { extract }\end{array}$ & In vivo & $\begin{array}{l}\text { Male } \\
\text { NMRI rats }\end{array}$ & $\begin{array}{l}0.1,0.25 \\
0.5 \mathrm{~g} / \mathrm{kg} ; \text { i.p. }\end{array}$ & $\begin{array}{l}\text { Thiobarbituric acid (TBA) and } \\
\text { ferric reducing antioxidant } \\
\text { power (FRAP) tests. }\end{array}$ & $\begin{array}{l}\downarrow \text { Brain MDA. } \\
\uparrow \text { Antioxidant power of brain. }\end{array}$ & $\begin{array}{l}{[38]} \\
\text { cont. }\end{array}$ \\
\hline
\end{tabular}

might be concluded due to the role of GABA and estrogen receptors in its antianxiety effect [36].

The protective potency of the hexane extract of the pistachio nut against oxidative stress has also been confirmed in a neuronal cell line via MTT and DCF-DA assays through focusing on its fatty acid composition [37].

With regard to antioxidant activity, the neuroprotective effects of $P$. vera gum extract have also been shown in rats with oxidative damage following cerebral ischemia. In this respect, the given extract could reduce the malondialdehyde (MDA) level and increase antioxidant capacity of the brain in comparison with those in the control group $[38,39]$. In another study, the hydroalcoholic extract of $P$. vera gum had been suggested to prolong sleep duration (at all doses: $0.25,0.5$, and $1 \mathrm{~g} / \mathrm{kg}$ ) and to shorten sleep onset latency $(1 \mathrm{~g} / \mathrm{kg})$. In addition, the administration of the extract in mice demonstrated its antianxiety effects and consequently suppressed locomotor activity in the open field test [40]. The antiepileptic effects of the hydroalcoholic extract of $P$. vera fruit have also been validated to be comparable with diazepam in a chronic PTZ-induced model of epilepsy in rats [41]. 
- Table 1 Continued

\begin{tabular}{|c|c|c|c|c|c|c|c|c|}
\hline $\begin{array}{l}\text { Scien- } \\
\text { tific } \\
\text { name }\end{array}$ & $\begin{array}{l}\text { Plant } \\
\text { part }\end{array}$ & $\begin{array}{l}\text { Extract/essen- } \\
\text { tial oil/active } \\
\text { compound }\end{array}$ & $\begin{array}{l}\text { In vivol } \\
\text { in vitro }\end{array}$ & $\begin{array}{l}\text { Animal } \\
\text { species }\end{array}$ & Dose/duration & Assay/method/model & Results & Ref \\
\hline \multirow[t]{9}{*}{$\begin{array}{l}\text { P. atlan- } \\
\text { tica }\end{array}$} & $\begin{array}{l}\text { Leaves, } \\
\text { flowers }\end{array}$ & Essential oil & In vitro & - & $500 \mu \mathrm{g} / \mathrm{mL}$ & $\begin{array}{l}\beta \text {-Carotene-linoleic acid assay; } \\
\text { DPPH and ABTS assays; } \\
\text { AChE inhibitory assay. }\end{array}$ & $\begin{array}{l}\text { Antioxidant activity. Anticho- } \\
\text { linesterase activity against } \\
\text { acetylcholinesterase and } \\
\text { butyrylcholinesterase. }\end{array}$ & [52] \\
\hline & Fruits & $\begin{array}{l}\text { Hydroalcoholic } \\
\text { extract }\end{array}$ & In vivo & $\begin{array}{l}\text { Gonadec- } \\
\text { tomized } \\
\text { rats }\end{array}$ & $\begin{array}{l}100 \mathrm{mg} / \mathrm{kg} \text { of } \\
\text { bane extract; } \mathrm{p} . \text { o., } \\
\text { daily for } 20 \text { days }\end{array}$ & $\begin{array}{l}\text { Elevated plus maze model of } \\
\text { anxiety. }\end{array}$ & $\begin{array}{l}\uparrow \text { The percentage of time spent } \\
\text { and entries in the open arms. }\end{array}$ & {$[53]$} \\
\hline & Fruits & $\begin{array}{l}\text { Hydroalcoholic } \\
\text { extract }\end{array}$ & In vivo & Male rats & $\begin{array}{l}400 \mathrm{mg} / \mathrm{kg} / \mathrm{bw} \\
\text { pistachio + } \\
\text { fluvoxamine } \\
120 \mathrm{mg} / \mathrm{kg} / \mathrm{bw}\end{array}$ & $\begin{array}{l}\text { Immobilization stress } \\
\text { radial arm maze test. }\end{array}$ & $\begin{array}{l}\downarrow \text { The time of reaching to target. } \\
\downarrow \text { MDA, corticosterone and blood } \\
\text { glucose level. } \\
\uparrow \text { CAT. }\end{array}$ & {$[54]$} \\
\hline & Leaves & $\begin{array}{l}\text { Aqueous } \\
\text { extract }\end{array}$ & In vitro & - & - & $\begin{array}{l}\text { AChE inhibitory assay. } \\
\text { Radical scavenging activity. }\end{array}$ & $\begin{array}{l}\text { AChE inhibitory activity. } \\
\downarrow \text { Hydroxyl, DMPD, superoxide } \\
\text { and ABTS. }\end{array}$ & {$[50]$} \\
\hline & Leaves & $\begin{array}{l}\text { Methanolic } \\
\text { extract, ethyl } \\
\text { acetate extract }\end{array}$ & In vitro & - & - & $\begin{array}{l}\text { Total antioxidant and free } \\
\text { radical scavenging activity. } \\
\beta \text {-Carotene bleaching test. } \\
\text { AChE inhibitory assay. }\end{array}$ & $\begin{array}{l}\text { Considerable antioxidant } \\
\text { property. } \\
\text { Slight AChE inhibitory activity. }\end{array}$ & {$[51]$} \\
\hline & $\begin{array}{l}\text { Oleo- } \\
\text { resin }\end{array}$ & $\begin{array}{l}\text { Methanol and } \\
\text { dichlorometh- } \\
\text { ane extracts }\end{array}$ & In vitro & - & - & AChE inhibitory assay. & $\begin{array}{l}\text { Dichloromethane extract: } \\
\text { AChE inhibitory activity. }\end{array}$ & {$[45]$} \\
\hline & Fruit & Essential oil & In vivo & $\begin{array}{l}\text { Rats, } \\
\text { mice }\end{array}$ & $\begin{array}{l}200,300 \text {, and } \\
500 \mathrm{mg} / \mathrm{kg}\end{array}$ & $\begin{array}{l}\text { Hole-board, rotarod, } \\
\text { catalepsy, } \\
\text { hypnotic, light/dark tests. }\end{array}$ & $\begin{array}{l}\text { CNS depressant, anxiolytic, } \\
\text { sedative and anti-inflammatory } \\
\text { properties. }\end{array}$ & {$[195]$} \\
\hline & Leaves & $\begin{array}{l}\text { Aqueous, ethyl } \\
\text { acetate, and } \\
\text { butanol ex- } \\
\text { tracts }\end{array}$ & In vitro & - & - & $\begin{array}{l}\text { DPPH; } \\
\text { AChE inhibitory assay. }\end{array}$ & $\begin{array}{l}\text { Antioxidant activity (maximum } \\
\text { in the ethyl acetate extract). } \\
\text { AChE inhibitory activity (ethyl } \\
\text { acetate and aqueous extracts). }\end{array}$ & {$[49]$} \\
\hline & Leaves & Aqueous extract & In vitro & - & - & AChE inhibitory assay & AChE inhibitory activity. & {$[43]$} \\
\hline \multirow[t]{7}{*}{$\begin{array}{l}\text { P. lentis- } \\
\text { cus }\end{array}$} & Leaves & Essential oil & In vivo & Rats & $200 \mathrm{mg}$ & $\begin{array}{l}\text { Bilateral common carotid } \\
\text { artery occlusion model. } \\
\text { Analysis of levels of the enzyme } \\
\text { COX-2, as assessed by Western } \\
\text { blot. }\end{array}$ & $\begin{array}{l}\uparrow \text { DHA. } \\
\downarrow \text { COX-2s. } \\
\uparrow \text { Palmytoylethanolamide and } \\
\text { oleoylethanolamide levels in } \\
\text { plasma. }\end{array}$ & {$[48]$} \\
\hline & Leaves & $\begin{array}{l}\text { Alcoholic } \\
\text { extract }\end{array}$ & In vitro & - & $\begin{array}{l}25,50 \\
100 \mu \mathrm{g} / \mathrm{mL}\end{array}$ & $\begin{array}{l}\text { SK-N-BE (2)-C cells injury in- } \\
\text { duced by } \mathrm{H}_{2} \mathrm{O}_{2} \text {, and } \mathrm{A} \beta(25-35) \\
\text { by the MTT assay. }\end{array}$ & $\begin{array}{l}\text { Protected the cells against } A \beta \\
(25-35) \text { and } \mathrm{H}_{2} \mathrm{O}_{2} \text {-induced toxic- } \\
\text { ity. }\end{array}$ & {$[47]$} \\
\hline & $\begin{array}{l}\text { Oleo- } \\
\text { resin }\end{array}$ & $\begin{array}{l}\text { Ethanolic } \\
\text { extract }\end{array}$ & In vitro & - & $\begin{array}{l}2,4,6,8 \\
10 \mu \mathrm{g} / \mathrm{mL}\end{array}$ & AChE inhibitory assay. & $\begin{array}{l}\text { Competitive inhibitor of acetyl- } \\
\text { cholinesterase. }\end{array}$ & {$[44]$} \\
\hline & Fruits & $\begin{array}{l}\text { Methanolic } \\
\text { extract }\end{array}$ & In vitro & - & - & $\begin{array}{l}\text { DPPH; ABTS. } \\
\text { Thioflavine T assay (ThT); } \\
\text { dynamic light scattering (DLS); } \\
\text { transmission electron micros- } \\
\text { copy analysis (TEM). }\end{array}$ & $\begin{array}{l}\text { Antioxidant activity. } \\
\text { Inhibited } A \beta 42 \text { aggregation and } \\
\text { related neurotoxicity. }\end{array}$ & {$[46]$} \\
\hline & Leaves & $\begin{array}{l}\text { Aqueous } \\
\text { extract }\end{array}$ & In vitro & - & - & AChE inhibitory assay. & AChE inhibitory activity & [43] \\
\hline & Fruit & Oil & In vivo & Male rats & $\begin{array}{l}3.3 \mathrm{~mL} / \mathrm{kg} \text { orally, } \\
\text { daily for } 15 \text { days }\end{array}$ & $\begin{array}{l}\text { Model of memory dysfunction } \\
\text { and oxidative stress induced by } \\
\text { lipopolysaccharide. } \\
\text { Open field and spatial object } \\
\text { recognition tests. } \\
\text { AChE inhibitory assay. }\end{array}$ & $\begin{array}{l}\downarrow \text { Spatial memory deficit. } \\
\downarrow \text { Brain acetylcholinesterase } \\
\text { activation. } \\
\downarrow \text { Brain MDA, } \mathrm{H}_{2} \mathrm{O}_{2} . \\
\uparrow \text { Brain CAT, SOD. }\end{array}$ & [42] \\
\hline & $\begin{array}{l}\text { Oleo- } \\
\text { resin }\end{array}$ & $\begin{array}{l}\text { Methanol and } \\
\text { dichlorometh- } \\
\text { ane extracts }\end{array}$ & In vitro & - & - & AChE inhibitory assay. & $\begin{array}{l}\text { Dichloromethane extract: AChE } \\
\text { inhibitory activity }\end{array}$ & $\begin{array}{l}{[45]} \\
\text { cont. }\end{array}$ \\
\hline
\end{tabular}


- Table 1 Continued

\begin{tabular}{|c|c|c|c|c|c|c|c|c|}
\hline $\begin{array}{l}\text { Scien- } \\
\text { tific } \\
\text { name }\end{array}$ & $\begin{array}{l}\text { Plant } \\
\text { part }\end{array}$ & $\begin{array}{l}\text { Extract/essen- } \\
\text { tial oil/active } \\
\text { compound }\end{array}$ & $\begin{array}{l}\text { In vivol } \\
\text { in vitro }\end{array}$ & $\begin{array}{l}\text { Animal } \\
\text { species }\end{array}$ & Dose/duration & Assay/method/model & Results & Ref \\
\hline \multirow[t]{3}{*}{$\begin{array}{l}\text { P. inte- } \\
\text { gerrima }\end{array}$} & Gall & $\begin{array}{l}\text { Crude extract, } \\
\text { ethyl acetate, } \\
\text { aqueous, } n- \\
\text { hexane and } \\
\text { chloroform } \\
\text { fraction; quer- } \\
\text { cetin, pyrogal- } \\
\text { lol }\end{array}$ & In vitro & - & $\begin{array}{l}1000,500,250 \\
125,62.5 \mu \mathrm{g} / \mathrm{mL}\end{array}$ & $\begin{array}{l}\text { DPPH; ABTS; } \\
\text { AChE inhibitory assay. }\end{array}$ & $\begin{array}{l}\text { Ethyl acetate fraction: the most } \\
\text { powerful radical scavenging ac- } \\
\text { tivity. } \\
\text { Quercetin and pyrogallol: anti- } \\
\text { oxidant properties. } \\
\text { Crude extract and ethyl acetate } \\
\text { fraction: highly inhibited acetyl } \\
\text { cholinesterase activity. }\end{array}$ & [57] \\
\hline & Galls & $\begin{array}{l}\text { Ethanolic } \\
\text { extract }\end{array}$ & In vivo & $\begin{array}{l}\text { Rats and } \\
\text { mice }\end{array}$ & 0.5 mL/kg; i. p. & $\begin{array}{l}\text { Five behavioral experimental } \\
\text { models. } \\
\text { Convulsion experimental mod- } \\
\text { els induced by PTZ, strychnine. } \\
\text { Maximal electroshock seizures } \\
\text { (IVIES). }\end{array}$ & $\begin{array}{l}\uparrow \text { Pentobarbitone-induced } \\
\text { sleeping. } \\
\uparrow \text { Time of loss of righting reflex. } \\
\uparrow \text { Reaction time of } 24 \mathrm{~h} \text { fasted } \\
\text { rats placed in a Hebb-William } \\
\text { maze. }\end{array}$ & [56] \\
\hline & Galls & Essential oil & In vitro & - & 10 and $50 \mu \mathrm{g} / \mathrm{mL}$ & $\begin{array}{l}\text { Pharmacological assays on } \\
\text { rabbit jejunum spontaneous } \\
\text { contractions, guinea pig ileum. }\end{array}$ & $\begin{array}{l}\uparrow \text { Isoprenaline induced relaxation } \\
\text { of rabbit jejunum, relaxation of } \\
\text { basal tone of } \mathrm{K}^{+} \text {induced contrac- } \\
\text { tion, } \downarrow \mathrm{Ca}^{2+} \text { induced contraction } \\
\text { of isolated guinea pig ileum in } \mathrm{Ca}^{2} \\
{ }^{+} \text {free medium. } \\
\uparrow \text { The reversal of a } \mathrm{KCl} \text {-induced } \\
\text { tonic contraction observed in } \mathrm{Ca}^{2} \\
{ }^{+} \text {free medium. }\end{array}$ & [196] \\
\hline \multirow[t]{2}{*}{$\begin{array}{l}\text { P. tere- } \\
\text { binthus }\end{array}$} & Flowers & $\begin{array}{l}\text { Aqueous } \\
\text { extract }\end{array}$ & In vivo & Male rats & $\begin{array}{l}250 \mathrm{mg} / \mathrm{kg} \text { every } \\
\text { other day by } \\
\text { gavage }\end{array}$ & $\begin{array}{l}\text { Measuring the lipid peroxi- } \\
\text { dation (LPO), total protein, } \\
\text { glutathione, and enzyme } \\
\text { activities in blood. }\end{array}$ & $\begin{array}{l}\downarrow \text { Lipid peroxidation in brain. } \\
\uparrow \text { Glutathione and total protein. } \\
\uparrow \text { GSH-Px and SOD. }\end{array}$ & [197] \\
\hline & Fruits & $\begin{array}{l}\text { Ethyl acetate } \\
\text { and methanolic } \\
\text { extracts }\end{array}$ & In vitro & - & - & $\begin{array}{l}\text { AChE inhibitory assay. Tyrosi- } \\
\text { nase activity assay. } \\
\text { DPPH, DMPD, FRAP and metal } \\
\text { chelation tests and PRAP test } \\
\text { as radical scavenging activity } \\
\text { assay. }\end{array}$ & $\begin{array}{l}\text { Methanolic extract moderately } \\
\text { inhibited butyrylcholinesterase } \\
\text { activity. } \\
\text { The extracts did not inhibit acetyl } \\
\text { cholinesterase and tyrosinase en- } \\
\text { zymes. } \\
\text { Both extracts: DPPH and DMPD } \\
\text { scavenging activity and antioxi- } \\
\text { dant activity. }\end{array}$ & [59] \\
\hline
\end{tabular}

AChE: Acetylcholinesterase; i. p.: intraperitoneal; DPPH: 2,2-diphenyl-1-picrylhydrazyl; PTZ: pentylenetetrazol; MDA: Malondialdehyde; ABTS: 2,2'-azino-bis (3-ethylbenzothiazoline-6-sulphonic acid); DMPD: N,N-dimethyl-p-phenylenediamine; SOD: Superoxide dismutase; CAT: catalase; GSH: Glutathione

\section{Pistacia lentiscus}

It has been reported that pretreatment by the essential oil of $P$. lentiscus fruit can attenuate lipopolysaccharide-induced memory impairment in rats in the open field and spatial object recognition tests. It can also induce a decrease in AChE activity as well as oxidative stress markers in brain tissues. The major components of the essential oil identified in this domain have been 4-(3-[(2hydroxybenzoyl) amino] aniline)-4-oxobut-2-enoic acid, $\beta$-myrcene, 3-pentadecylphenol, P-tolyl ester, aminoformic acid, and $\beta$-sitosterol [42]. Other studies have also demonstrated that the aqueous extract of $P$. lentiscus leaves and the ethanolic extract of its oleoresin possessed AChE inhibitory activity with $\mathrm{IC}_{50}$ values of $13.67 \pm 0.69 \mu \mathrm{g} / \mathrm{mL}$ and $6.5 \mu \mathrm{g} / \mathrm{mL}$, respectively $[43,44]$. Additionally, the dichloromethane extract of $P$. lentiscus oleoresin has also been shown to inhibit AChE activity [45]. In this respect, Dhouafli et al. [46] investigated $P$. lentiscus for its ability to coun- teract amyloid ( $A \beta 42$ ) aggregation, commonly considered a pathological hallmark of $A D$ [47]. The results of this study indicated that pretreatment in SH-SY5Y cells with $100 \mu \mathrm{g} / \mathrm{mL}$ of defatted methanol extract of $P$. lentiscus $(10 \mu \mathrm{g} / \mathrm{mL})$ for $24 \mathrm{~h}$ could increase cell viability and reduce $A \beta$-mediated cellular toxicity. However, $P$. lentiscus extract did not have a significant cytoprotective effect. In contrast, cells treated with the same amount of $A \beta 42$ aggregates grown in the presence of the extract showed significant retention of viability, reaching $81.65 \%$ for $P$. lentiscus [46]. The alcoholic extract obtained from $P$. lentiscus leaves has also been demonstrated to contain substantial amounts of phenolic components as effective agents for preventing disorders induced by oxidative damage. This extract could significantly protect SK-N-BE (2)- $\mathrm{C}$ neuronal cells against oxidative injury by $\mathrm{H}_{2} \mathrm{O}_{2}$ and $\mathrm{A} \beta$ (2535 ) and almost entirely protect the given cells against $A \beta$-induced neuronal toxicity with the dose of $100 \mu \mathrm{g} / \mathrm{mL}$ [47]. Besides, ische- 


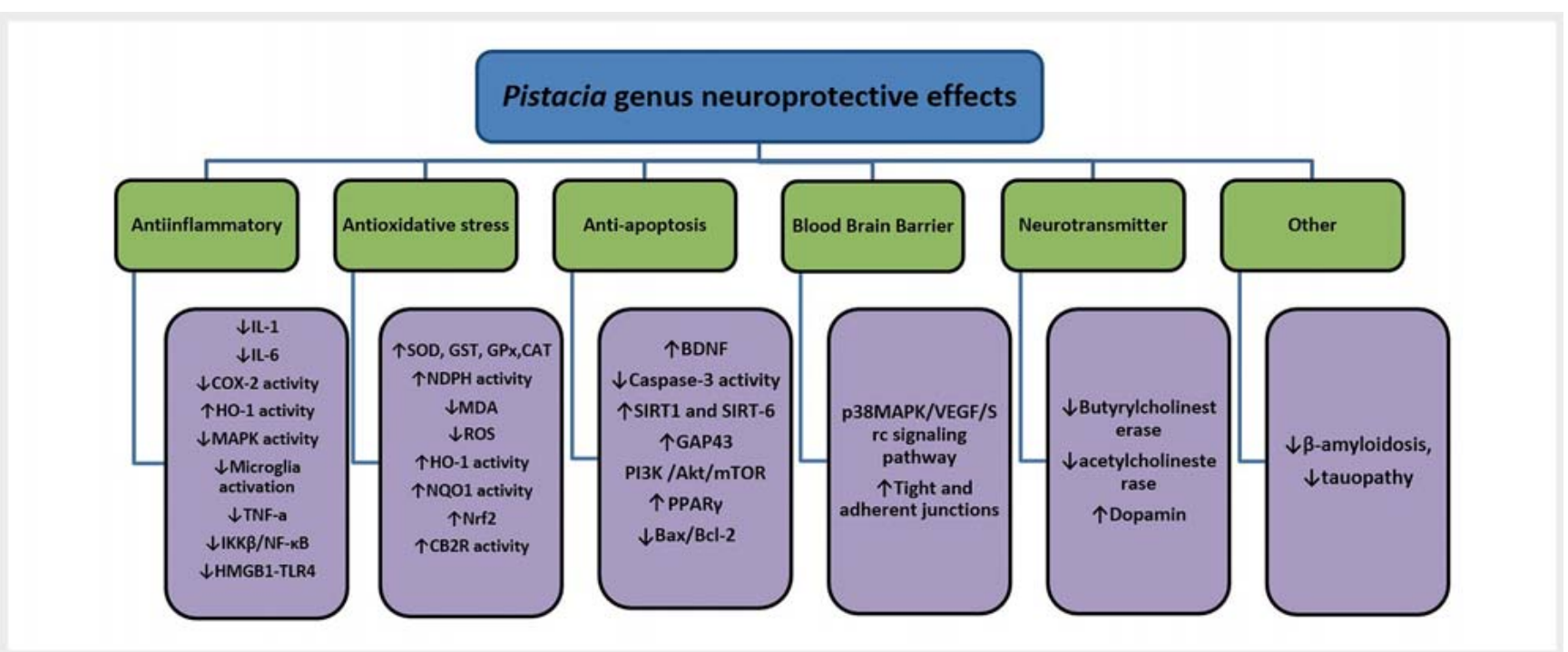

- Fig. 2 Molecular mechanisms of Pistacia in neuroprotection.

mia of the brain causes free radical formation, neuroinflammation, and neuronal injury. In an ischemic model of bilateral common carotid artery ligation, the essential oil of $P$. lentiscus leaves was able to reverse ischemia-induced decrease of docosahexaenoic acid (DHA) and COX-2 expression in the frontal cortex. It is noteworthy that DHA is the predominant fatty acid of neuronal cell membrane affected by oxidative damage. It also acts through stimulating PPAR- $\alpha$, which results in diminishing neuroinflammation. Moreover, COX-2 overexpression induced by ischemia can contribute to neuronal injury. Additionally, the essential oil increases the amount of palmitoylethanolamide (PEA) and oleoylethanolamide (OEA) as well as DHA biosynthesis in plasma, which counteract neuroinflammation. The increase in DHA biosynthesis can be induced by elevated levels of PEA and OEA followed by PPAR- $\alpha$ activation. This potential mechanism eventually leads to a neuroprotective effect of $P$. lentiscus essential oil against ische$\mathrm{mia} /$ reperfusion brain injury [48].

\section{Pistacia atlantica}

The most effective AChE inhibitory activity of the extracts of $P$. atlantica leaves has been reported by ethyl acetate and aqueous extracts, probably due to the high phenolic components in these substances [49]. The results of two studies in this domain demonstrated that the aqueous extract of $P$. atlantica leaves possessed remarkable $\mathrm{AChE}$ inhibitory activity with an $\mathrm{IC}_{50}$ of $0.87 \pm$ $0.55 \mu \mathrm{g} / \mathrm{mL}$ [43] and $58.05 \pm 0.12 \mu \mathrm{g} / \mathrm{mL}$ [50], respectively. It should be noted that $P$. atlantica consists of large amounts of phenolic compounds, possibly associated with the strong AChE inhibitory effect $[43,50]$. In addition, anticholinesterase and antioxidant activities of methanolic and ethyl acetate extracts of $P$. atlantica leaves have been assessed. In this regard, powerful antioxidant properties have been observed by both extracts compared with known synthetic antioxidants. It should be noted that the antioxidant properties of $P$. atlantica leaf extracts can be attributed to their constituents, including total phenols, total flavo- noids, anthocyanins, chlorophyll, and carotenoid contents. In addition, the extracts have demonstrated slight inhibitory activity against AChE. However, ethyl acetate extract could inhibit the enzyme much stronger than the methanolic extract [51].

Essential oils obtained from $P$. atlantica leaves and flowers have further been found to be protective against free radicals and oxidative stress. They can also inhibit the AChE enzyme. It is worth noting that the essential oils consist of large amounts of monoterpenes and oxygenated sesquiterpenes contributed to the antioxidant and anticholinesterase properties. Moreover, the effects of $P$. atlantica leaf essential oil on both free radical scavenging and anticholinesterase activities have been reported to be, to some degree, better than its flower oil. P. atlantica leaf oil has also shown an $\mathrm{IC}_{50}$ of $18.5 \pm 0.5$ compared with $P$. atlantica flower oil, which has an $\mathrm{IC}_{50}$ of $20.5 \pm 0.5 \mu \mathrm{g} / \mathrm{mL}$ against AChE [52].

In one animal study, anxiety-like behaviors were assessed using the elevated plus maze (EPM) test in intact and gonadectomized rats submitted to a chronic unpredictable stress (CUS) paradigm and treated with hydroalcoholic extracts of $P$. atlantica fruit (100 mg/kg, orally for 20 days). The results of this study revealed that $P$. atlantica treatment increased the percentage of both time spent and entries in the open arms of EPM in intact and gonadectomized rats. Moreover, the effects of chronic stress were reversed by $P$. atlantica treatment [53]. Administration of the hydroalcoholic extract of $P$. atlantica fruit $(400 \mathrm{mg} / \mathrm{kg})$ in combination with fluvoxamine in rats under immobilization stress also improved spatial memory via decreasing the time of reaching the target as well as reducing the MDA, corticosterone, and blood glucose levels and increasing the catalase level [54].

Pretreatments with noncytotoxic P. atlantica extract at $100 \mu \mathrm{g} /$ $\mathrm{mL}$ have similarly been reported to reduce starvation-induced apoptosis in vitro. Pretreatments with $P$. atlantica have also been demonstrated to be neuroprotective against PD-inducing neurotoxins, including 6-OHDA and rotenone [55]. 


\section{Pistacia integerrima}

In this domain, Ansari et al. [56] found that pretreatment of rats with the ethanolic extract of $P$. integerrima galls could possess a CNS-depressant activity once administered $(0.5 \mathrm{~mL} / \mathrm{kg}$; i. p.) in rats. It could also extend the duration of sleeping in a pentobarbiton-induced sleeping model. Moreover, its extract could remarkably inhibit aggressive behaviors in isolated mice. As well, the administration of the given extract had significantly protected the mice against tonic-clonic convulsion and death induced by PTZ. Its major identified constituents were $\alpha$-terpineol, $\beta$-terpineol, $\alpha$ pinene, $\beta$-pinene, A3-carnene, $\alpha$-phellandrene, $\beta$-phellandrene, 6 pinene, $\alpha$-terpenene, limonene $\alpha$-ocemene, and $\beta$-ocemene.

In another study, several types of $P$. integerrima gall extracts had been studied in order to identify radical scavenging and cholinesterase inhibitory activity. Among them, ethyl acetate extract demonstrated the best radical scavenging activity in both DPPH and ABTS assays as well as the most potent AChE and butyrylcholinesterase inhibitory activities compared with other tested extracts. $P$. integerrima crude extract also showed both AChE inhibitory and radical scavenging activities, which were approximately closer to the ethyl acetate extract. Free radical scavenging activity of quercetin and pyrogallol as pure compounds isolated from $P$. integerrima was also confirmed, with higher antioxidant properties for pyrogallol [57].

It has also been reported that the petroleum ether extract of $P$. integerrima gall could display anticonvulsant activity in zebrafish through prolonging the onset of hyperactivity and tonic-clonic seizure in PTZ-induced seizures $(50,100,200 \mathrm{mg} / \mathrm{kg})$. Additionally, anticonvulsant effects of the petroleum ether extract have been confirmed in mice at doses of 100 and $150 \mathrm{mg} / \mathrm{kg}$. Besides, petroleum ether extract delayed or prevented hind limb extension onset in maximal electroshock models of epilepsy in a dose-dependent manner. In contrast, methanolic extract proved to have no protection against seizures in both PTZ and MES models [58]. The essential oil of $P$. integerrima gall also revealed relaxant and spasmolytic effects in one study, probably mediated by modulating $\beta$-adrenoceptors and calcium channels [27].

\section{Pistacia terebinthus}

The anticholinesterase and antioxidant properties of ethyl acetate and methanolic extracts of $P$. terebinthus fruit and four terebinth coffee brands were investigated in an in vitro study. The results showed that both extracts had moderate inhibitory effects on butyrylcholinesterase activity (at the concentration of $200 \mu \mathrm{g} / \mathrm{mL}$ ). Moreover, they showed radical scavenging activity at a higher concentration $(2000 \mu \mathrm{g} / \mathrm{mL})$ without inhibiting the activity of AChE and tyrosinase enzymes. It has been reported that phenolic and flavonoid contents of terebinth coffee brands are higher than $P$. terebinthus fruit, which results in higher antioxidant and neuroprotective activities. The increase in phenolic and flavonoid content may be due to the roasting process, which implies that the roasting process of fruit may improve the antioxidant properties of the extracts. It has also been reported that oleic acid is the major fatty acid found in $P$. terebinthus fruits, while $\alpha$-pinene is the main constituent in the essential oil followed by $\beta$-ocimene and limonene [59].

\section{Neuroprotective Phytochemicals in Pistacia Genus}

Herbal medicine or phytotherapy generally refers to the medicinal usage of plant parts with their secondary metabolites for their curative properties. Different usable plant parts in the Pistacia genus also contain a variety of bioactive phytochemicals [9]. Phytochemicals are biologically active compounds that are not considered essential nutrients but seem to contribute to protection against degenerative disease [60].

Among the edible parts of the herbs in this genus, pistachio fruits (i.e., kernels) are the most extensively used nuts as food. From a nutritional point of view, Pistacia species have fruits with remarkable contents of fatty acids. The main fatty acid in kernels of $P$. vera, $P$. atlantica, $P$. lentiscus, and $P$. terebinthus fruits is oleic acid [22], which has been proven to be protective as an unsaturated fatty acid against AD as well as other neurological disorders [61]. Besides the other fatty acids identified in these species, linolenic has been known as the precursor of DHA and eicosapentaenoic acids (EPAs) and it has been reported to possess antioxidative and neuroprotective effects [62]. Polyunsaturated fatty acids (PUFAs) have been shown to play a central role in the maintenance of neuronal functions and brain development, contributing to neurogenesis and neuroplasticity. Moreover, these PUFAs also exert significant protective effects against inflammatory damage to the neurons and glial cells. Omega-3 fatty acids have also been reported to show promising effects as antidepressant agents [63].

The presence of other nutrients such as glutamic and aspartic acids, vitamins (vitamin E), choline, and phytosterols (i.e., $\beta$-sitosterol, campesterol, and stigmasterol) could also emphasize the potential of these seeds (especially pistachios) in the prevention and control of neurological diseases [64]. Along with the nutrient dense kernels, various groups of phytochemicals, mostly terpenes (mono-, sesqui-, and triterpenes) and phenolic compounds, have been identified in different plant parts of Pistacia species. Many studies have shown a neuroprotective effect of Pistacia chemical constituents. Selected studies examining the key components in this domain are summarized in D Table 2 and are shown in - Fig. 2.

\section{Terpenes}

Terpenes and terpenoids (modified terpenes) are the principal constituents of the essential oils in many types of plants. Their classification is commonly based on isoprene units. Essential oils mostly contain mono- (with two isoprene units) and sesquiterpenoids (with three isoprene units) [65]. Monoterpenes are the predominant constituents of the essential oil obtained from leaves, oleoresin, and fruits of different Pistacia species [22]. The galls are also rich in terpenes. The galls usually contain higher levels of total terpene, especially monoterpenes like $\alpha$-pinene and limonene, while the healthy leaves possess higher contents of sesquiterpenes with a predominance of caryophyllene, germacrene D, and d-cadinene [66]. 
- Table 2 Selected phytochemicals in the Pistacia genus and their neuroprotective activity.

\begin{tabular}{|c|c|c|c|c|}
\hline $\begin{array}{l}\text { Scientific } \\
\text { name }\end{array}$ & Plant parts [22] & $\begin{array}{l}\text { Constit- } \\
\text { uents }\end{array}$ & Experimental model & Observation/mechanism \\
\hline P. vera & $\begin{array}{l}\text { Leaf, } \\
\text { unripe fruit, } \\
\text { resin }\end{array}$ & \multirow[t]{6}{*}{$\alpha$-Pinene } & $\begin{array}{l}\mathrm{H}_{2} \mathrm{O}_{2} \text {-induced oxidative stress in } \\
\text { rat } \mathrm{PC} 12\end{array}$ & $\begin{array}{l}\uparrow \text { Cell viability } \\
\downarrow \text { Intracellular ROS } \\
\uparrow \text { CAT, SOD, GPX, GR, HO-1 } \\
\downarrow \text { Apoptosis } \\
\downarrow \text { Capase-3 } \\
\uparrow \text { Nrf2 [71] }\end{array}$ \\
\hline P. terebinthus & $\begin{array}{l}\text { Fruit, } \\
\text { aerial part, } \\
\text { leaf, gall }\end{array}$ & & 6-OHDA-induced PD in rat & $\begin{array}{l}\text { Improvement of the movement disorder and avoidance memory } \\
\downarrow \text { MDA in striatum and hippocampus [73] }\end{array}$ \\
\hline P. lentiscus & $\begin{array}{l}\text { Resin, leaf } \\
\text { fruit, aerial part }\end{array}$ & & Inhalation of $\alpha$-pinene in mouse & $\begin{array}{l}\downarrow \text { Anxiety } \\
\text { Accumulation of } \alpha \text {-pinene in the brain and liver [198] }\end{array}$ \\
\hline \multirow[t]{3}{*}{ P. atlantica } & \multirow{3}{*}{$\begin{array}{l}\text { Leaf, fruit, gall, } \\
\text { resin }\end{array}$} & & Inhalation of $\alpha$-pinene in mouse & $\uparrow$ BDNF in the olfactory bulb and in the hippocampus [74] \\
\hline & & & $\begin{array}{l}\text { Scopolamine-induced cognitive } \\
\text { dysfunction in mouse }\end{array}$ & $\begin{array}{l}\uparrow \text { Choline acetyltransferase } \\
\uparrow \text { Nrf2 } \\
\text { Improvement of cognitive dysfunction [72] }\end{array}$ \\
\hline & & & $\begin{array}{l}\text { Dizocilpine-induced schizophre- } \\
\text { nia-like behavior }\end{array}$ & $\begin{array}{l}\downarrow \text { Behavioral alteration } \\
\downarrow \text { Total distance travelled in the Y-maze test } \\
\downarrow \text { Activity of mice in the spontaneous locomotor activity test [75] }\end{array}$ \\
\hline \multirow[t]{5}{*}{ P. lentiscus } & \multirow[t]{5}{*}{ Mastic water } & \multirow[t]{5}{*}{ Linalool } & $\begin{array}{l}\text { Acrylamide-induced neurotoxic- } \\
\text { ity in rat }\end{array}$ & $\begin{array}{l}\uparrow \text { GSH } \\
\downarrow \text { Lipid peroxidation [77] }\end{array}$ \\
\hline & & & $\begin{array}{l}\text { OGD/R-induced cortical neu- } \\
\text { ronal injury in microglial cell }\end{array}$ & $\begin{array}{l}\downarrow \text { Cells death } \\
\downarrow \text { Intracellular ROS } \\
\uparrow \text { SOD, CAT } \\
\downarrow \text { Microglial migration [78] }\end{array}$ \\
\hline & & & $\begin{array}{l}\text { Triple transgenic model of } A D \\
(3 \times \mathrm{Tg}-\mathrm{AD}) \text { in aged mouse }\end{array}$ & $\begin{array}{l}\text { Improvement of learning and spatial memory } \\
\downarrow \text { Extracellular } \beta \text {-amyloidosis, tauopathy, astrogliosis and micro- } \\
\text { gliosis } \\
\downarrow \text { p38 MAPK, NOS2, COX2, IL-1 } \beta[76]\end{array}$ \\
\hline & & & $\begin{array}{l}\text { MCAO-induced ischemic neuro- } \\
\text { degeneration in rat } \\
\text { Glutamate induced toxicity in } \\
\text { glial cell }\end{array}$ & $\begin{array}{l}\downarrow \text { Infarct volume } \\
\text { Better neurological and motor skills and relearning performance } \\
\downarrow \text { Microgliosis, COX-2, IL-1B and Nrf2 markers } \\
\downarrow \text { NF- } k \text { B, IL1- } \beta, \text { COX-2, and Nrf2 immunostaining and microglial } \\
\text { changes under glutamate toxicity [79] }\end{array}$ \\
\hline & & & $\begin{array}{l}\text { Expression of recombinant T- } \\
\text { type Ca2+ channels (Cav3.2) in } \\
\text { HEK-293 T cells using whole-cell } \\
\text { patch-clamp technique }\end{array}$ & $\begin{array}{l}\downarrow \text { Cav} 3.2 \\
\text { Inhibition of TTCCs [199] }\end{array}$ \\
\hline
\end{tabular}

\section{$\alpha$-Pinene}

$\alpha$-Pinene is a bicyclic monoterpene widely found in nature, especially in essential oils with a strong turpentine odor $[67,68]$. This substance forms a large part of the essential oil of the Pistacia genus from $57.06 \%$ [69] in P. atlantica to $75.6 \%$ in P. vera [70].

Antioxidant activity of $\alpha$-pinene has been shown through its beneficial effect on the equilibration of oxidant/antioxidant to protect against $\mathrm{H}_{2} \mathrm{O}_{2}$-induced oxidative stress in rat PC12 cells. Reactive oxygen species scavenging and induction of the Nrf2 were determined as the main mechanisms of action [71]. In another study, $\alpha$-pinene was administered in C57BL/6 mice with scopolamine-induced cognitive dysfunction. Increasing mRNA expression of choline acetyltransferase, hemeoxygenase- 1 (HO-1) and activation of $\mathrm{Nrf2}$ were the main mechanisms of the $\alpha$-pinene beneficial effect for management of dementia [72]. In addition, in mice with 6-OHDA-induced PD, administration of $\alpha$-pinene im- proved the movement disorder and avoidance memory. It led to a reduction in the MDA level in the striatum and hippocampus [73]. This substance has been shown to exert anxiolytic effects as well. Inhalation of $\alpha$-pinene in mice increased BDNF mRNA and tyrosine hydroxylase mRNA in the olfactory bulb and in the hippocampus. It also increased locomotor activity and acted as an anxiolytic agent based on the elevated plus maze test [74]. Another animal study evaluated the effects of $\alpha$-pinene inhalation on mice with dizocilpine-induced schizophrenia-like behavior. Inhalation of $\alpha$-pinene suppressed the dizocilpine-induced increased total distance travelled in the Y-maze test, whereas it did not alter the MK-801-induced reduced threshold of antinociception in the hot plate test. Inhalation of $\alpha$-pinene suppressed the activity of mice in the spontaneous locomotor activity test and although it did not suppress the dizocilpine-induced increased locomotor activity in the open field test, it remarkably decreased the time that the mice 
- Table 2 Continued

\begin{tabular}{|c|c|c|c|c|}
\hline $\begin{array}{l}\text { Scientific } \\
\text { name }\end{array}$ & Plant parts [22] & $\begin{array}{l}\text { Constit- } \\
\text { uents }\end{array}$ & Experimental model & Observation/mechanism \\
\hline P. terebinthus & Leaf & \multirow{14}{*}{$\begin{array}{l}\beta \text {-caryo- } \\
\text { phyllene }\end{array}$} & OGD/R-induced ischemia in hu- & Significant neuroprotection effect (more than MK 801, the posi- \\
\hline \multirow[t]{13}{*}{ P. lentiscus } & \multirow[t]{13}{*}{ Leaf, galls } & & & \\
\hline & & & $\begin{array}{l}\text { LPS-induced toxicity in a prolif- } \\
\text { erative oligodendrocyte cell line } \\
\text { (OLN-93) }\end{array}$ & $\begin{array}{l}\downarrow \text { Toxicity } \\
\text { Involvement of CB2R through different pathways including Nrf2/ } \\
\text { HO-1/antioxidant axis, and PPAR-y [200] }\end{array}$ \\
\hline & & & $\begin{array}{l}\text { High-fat/fructose diet-induced } \\
\text { neurobehavioral changes in rats }\end{array}$ & $\begin{array}{l}\downarrow \text { OS } \\
\downarrow \text { Neuroinflammation and behavioral changes } \\
\text { Involvement of CB2R in antidepressant and memory improvement } \\
\text { by upregulation of PGC- } 1 \alpha \text { and BDNF } \\
\text { Involvement of PPAR- } y \text { and CB2R in anxiolytic, antioxidant, and } \\
\text { anti-inflammatory effects [87] }\end{array}$ \\
\hline & & & $\begin{array}{l}\mathrm{Cl} / \mathrm{R} \text { injury in } \mathrm{C} 57 \mathrm{BL} / 6 \text { mice. } \\
\mathrm{OGD} / \mathrm{R} \text {-induced ischemia in vitro }\end{array}$ & $\begin{array}{l}\downarrow \text { Necroptotic neurons and MLKL protein } \\
\downarrow \text { Infarct volumes, neuronal necrosis, RIPK1 and RIPK3 expression, } \\
\text { and MLKL phosphorylation. } \\
\downarrow \text { HMGB1, TLR4, IL-1 } \beta \text {, and TNF- } \alpha \text { levels [91] }\end{array}$ \\
\hline & & & Cl-R injury in rat & $\begin{array}{l}\downarrow \text { Neurological deficit scores, infarct volume, MDA, LPO, NO, Bax } \\
\uparrow \text { SOD, CAT and Bcl-2 } \\
\uparrow \text { Nrf2, HO- } 1 \text { [92] }\end{array}$ \\
\hline & & & $\begin{array}{l}\text { MPTP-induced murine model of } \\
\text { PD }\end{array}$ & $\begin{array}{l}\downarrow \text { Motor dysfunction } \\
\downarrow \text { Glia activation } \\
\downarrow \text { Dopaminergic neuronal losses } \\
\downarrow \text { Inflammatory cytokines in the nigrostriatal system. } \\
\text { Involvement of the CB2R [88] }\end{array}$ \\
\hline & & & $\begin{array}{l}\text { Rotenone-induced oxidative } \\
\text { stress and neuroinflammation in } \\
\text { a rat model of PD }\end{array}$ & $\begin{array}{l}\downarrow \text { Dopaminergic neurons death } \\
\downarrow \text { Microglia and astrocyte activation } \\
\downarrow \text { lba- } 1 \text { and GFAP expression } \\
\downarrow \text { COX-2, iNOS, lipid peroxidation, glutathione depletion } \\
\uparrow \text { Antioxidant enzymes [201] }\end{array}$ \\
\hline & & & $\begin{array}{l}\text { Kainic acid-induced seizure } \\
\text { activity in mouse }\end{array}$ & $\begin{array}{l}\downarrow \text { Seizure activity score } \\
\downarrow \text { Mortality } \\
\downarrow \text { MAO, TNF- } \alpha \text {, and IL- } 1 \beta \\
\uparrow \mathrm{GPx}, \text { SOD, CAT [202] }\end{array}$ \\
\hline & & & $\begin{array}{l}\text { Pentylenetetrazol-induced } \\
\text { seizures in mouse }\end{array}$ & $\begin{array}{l}\uparrow \text { Latency to myoclonic jerks } \\
\text { Improvement of recognition index } \\
\text { No behavioral changes in open field, rotarod, or forced swim tests } \\
\text { No effect on TBAR and NPT [203] }\end{array}$ \\
\hline & & & $\begin{array}{l}\text { Transgenic APP/PS1 model of AD } \\
\text { in mouse }\end{array}$ & $\begin{array}{l}\downarrow \text { Cognitive impairment } \\
\downarrow \beta \text {-amyloid } \\
\downarrow \text { Astrogliosis and microglial activation } \\
\downarrow \text { COX-2 protein and the mRNA levels of TNF- } \alpha \text { and IL- } 1 \beta \text { in the } \\
\text { cerebral cortex [84] }\end{array}$ \\
\hline & & & $\begin{array}{l}\text { MCAO-induced ischemia } \\
\text { OGD/R in cerebral cells }\end{array}$ & $\begin{array}{l}\downarrow \text { Neurological deficits } \\
\downarrow \mathrm{iNO} \text {, IL-1 } \beta, \text { IL-6, and COX-2 in C6 microglial cells } \\
\downarrow \mathrm{NO} \text { and } \mathrm{PGE}_{2}[90]\end{array}$ \\
\hline & & & $\begin{array}{l}\text { Animal model of vascular } \\
\text { dementia in rat }\end{array}$ & $\begin{array}{l}\downarrow \text { Learning and memory deficits } \\
\uparrow \text { Recovery of cerebral brain flow } \\
\uparrow \text { Expression of CB2 } \\
\uparrow \text { Expression levels of PI3K and Akt [82] }\end{array}$ \\
\hline & & & $\begin{array}{l}\text { Glutamate-induced cytotoxicity } \\
\text { in the C6 glioma cell line }\end{array}$ & $\begin{array}{l}\downarrow \text { ROS } \\
\text { Reestablishing } \Delta \psi_{\mathrm{m}} \\
\uparrow \text { Nuclear translocation of Nrf2 } \\
\uparrow \mathrm{GSH} \\
\text { Involvement of CB2R activation [85] }\end{array}$ \\
\hline
\end{tabular}


- Table 2 Continued

\begin{tabular}{|c|c|c|c|c|}
\hline $\begin{array}{l}\text { Scientific } \\
\text { name }\end{array}$ & Plant parts [22] & $\begin{array}{l}\text { Constit- } \\
\text { uents }\end{array}$ & Experimental model & Observation/mechanism \\
\hline P. lenticus & $\begin{array}{l}\text { Fruit, resin, } \\
\text { leaves, twigs }\end{array}$ & \multirow[t]{3}{*}{ Myrcene } & \multirow[t]{3}{*}{$\begin{array}{l}\text { Global CI/R by carotid occlusion } \\
\text { in C57BL/J6 mouse }\end{array}$} & \multirow{3}{*}{$\begin{array}{l}\uparrow \text { GSH, GPx, and SOD } \\
\downarrow \text { TBARs } \\
\downarrow \text { Histopathological damage and apoptosis in brain tissue [96] }\end{array}$} \\
\hline P. atlantica & Fruit, resin, leaves & & & \\
\hline P. vera & Fruit, leaves, hulls & & & \\
\hline P. atlantica & gum & \multirow[t]{5}{*}{ Limonene } & \multirow{2}{*}{$\begin{array}{l}\text { Corticosterone-induced neuro- } \\
\text { toxicity in } \mathrm{PC} 12\end{array}$} & $\downarrow$ Neurotoxicity \\
\hline P. terebinthus & fruit & & & $\begin{array}{l}\downarrow \text { MDA, NO, NADPH oxidase, iNOS, COX-2, IL-6, IL-1 } \beta \text {, and TNF- } \alpha \text {, } \\
\downarrow \text { Bax and cleaved caspase-3 } \\
\uparrow \text { SOD } 1, \text { HO- } 1, \text { BCl-2 } \\
\downarrow \text { Number of TUNEL-positive cells } \\
\uparrow \text { AMPK } \alpha \text { and } \downarrow \text { of NF- } \kappa \text { B nuclear translocation through upregula- } \\
\text { tion of SIRT1 [97] }\end{array}$ \\
\hline \multirow[t]{3}{*}{ P. lentiscus } & \multirow[t]{3}{*}{ Resin, fruit } & & $\begin{array}{l}\text { Chronic immobilization stress- } \\
\text { induced high anxiety in male rat }\end{array}$ & $\begin{array}{l}\uparrow \text { Percentage of open arm entries and stay in these arms } \\
\downarrow \text { Stress-induced damage in CA1 pyramidal neurons [98] }\end{array}$ \\
\hline & & & $\begin{array}{l}\text { Transient cerebral ischemia in } \\
\text { stroke-prone spontaneously } \\
\text { hypertensive rats }\end{array}$ & $\begin{array}{l}\downarrow \text { Cerebral infarct size } \\
\downarrow \text { mRNA expression of IL- } 1 \beta \text {, MCP- } 1 \text {, and COX-2 } \\
\uparrow \text { mRNA expression of VEGF in the brain } \\
\uparrow \text { SOD, CAT } \\
\uparrow \text { Glutathione } \\
\downarrow \text { MDA } \\
\text { Improvement of behavior [99] }\end{array}$ \\
\hline & & & Scopolamine-induced dementia & $\begin{array}{l}\text { Improvement of associative and non-associative memory } \\
\uparrow \text { Dopamine } \\
\downarrow \text { AChE activity [100] }\end{array}$ \\
\hline
\end{tabular}

remained in the central area. In the tail suspension and grip strength tests, there was no effect on mouse behavior by administration of MK-801 (dizocilpine) and inhalation of $\alpha$-pinene [75].

\section{Linalool}

Linalool (3,7-Dimethyl-1,6-octadien-3-ol) refers to two enantiomers of a naturally occurring terpene alcohol that is a major volatile component of over 200 essential oils of several aromatic plants. It has remarkable effects as a sedative, antinociceptive, anticonvulsant, and anxiolytic natural product [76]. Linalool administration in rats that were exposed to acrylamide, as a neurotoxic agent, led to an increase of glutathione content and reduction of acrylamide-induced lipid peroxidation in rat brain tissue [77].

In an in vitro study, (-)-linalool also demonstrated neuroprotective effects against neuronal injury induced by oxygenglucose deprivation/reoxygenation (OGD/R). Antioxidant and anti-inflammatory properties of $(-)$-linalool might be related to this effect [78].

Oral administration of this monoterpene led to an improvement in learning and spatial memory and greater risk assessment behavior in old triple transgenic AD mice. A significant reduction in microgliosis, astrogliosis, extracellular $\beta$-amyloidosis, and tauopathy were detected in hippocampi and amygdalae from linalool-treated mice. Proinflammatory markers p38 mitogen-activated protein kinase (MAPK), NOS2, COX-2, and IL-1 $\beta$ also decreased [76]. Moreover, intranasal administration of linalool after focal-in- duced ischemia in rats led to a reduction in infarct volume, and better neurological and motor skills. In this study, attenuation of microgliosis and COX-2, IL-1 $\beta$, and Nrf2 markers in the cerebral cortex and hippocampus was detected [79].

\section{$\beta$-Caryophyllene}

$\beta$-Caryophyllene, also known as caryophyllene or (-)- $\beta$-caryophyllene, is a natural bicyclic sesquiterpene that is a constituent of many essential oils. It is usually found in nature as a mixture with small amounts of isocaryophyllene (the cis double bond isomer) and $\alpha$-humulene ( $\alpha$-caryophyllene) isomers [80]. Various studies have shown neuroprotective effects of $\beta$-caryophyllene in animal models of cerebral ischemia, PD, and AD. It has also been shown as an anxiolytic, anticonvulsant, analgesic, immunomodulator, and antispasmodic agent. Machado et al. [81] have recently reviewed the neuroprotective perspective of this natural product. $\beta$-Caryophyllene appears to act as a neuroprotective agent by controlling inflammation and oxidative stress as well as various effects on cannabinoid receptor 2 (CB2) [80-82]. In a vascular dementia rat model study, Lou et al. [82] reported that $\beta$-caryophyllene-hydroxypropyl- $\beta$-cyclodextrin inclusion complex could alleviate cognitive deficits by increasing the expression of CB2 in the brain, along with the expression levels of phosphoinositide 3-kinase ( $\mathrm{PI} 3 \mathrm{~K})$ and protein kinase $\mathrm{B}(\mathrm{Akt})$. $\beta$-Caryophyllene also acted as agonist for CB2 and PPAR- $\alpha$ receptors in an animal hypoperfusion-reperfusion model of oxidative stress, and modulated activation of the endocannabinoid system and lipoperoxidation as well 
- Table 2 Continued

\begin{tabular}{|c|c|c|c|c|}
\hline $\begin{array}{l}\text { Scientific } \\
\text { name }\end{array}$ & Plant parts [22] & $\begin{array}{l}\text { Constit- } \\
\text { uents }\end{array}$ & Experimental model & Observation/mechanism \\
\hline P. lentiscus & Resin [103] & $\begin{array}{l}\text { Ursolic } \\
\text { acid }\end{array}$ & $\begin{array}{l}\text { Transient MCAO-induced focal } \\
\text { cerebral ischemia in the mouse }\end{array}$ & $\begin{array}{l}\text { Improvement of neurological deficit } \\
\downarrow \text { Infarct size } \\
\downarrow \text { Lipid peroxidation } \\
\uparrow \text { Nrf2 pathway } \\
\downarrow \text { TLR4, NF- } \mathrm{B} B \\
\text { More severe neurologic deficits, infarct size and inflammatory } \\
\text { damage [125] }\end{array}$ \\
\hline \multirow[t]{15}{*}{ P. vera } & Kernel [104] & & $A \beta(25-35)$-induced toxicity in & $\downarrow$ iNOS and COX-2 through inhibition of NF- $\kappa$ B activity \\
\hline & \multirow[t]{14}{*}{ Resin } & & PC12 cells & $\downarrow$ ERK1/2, p-38, and JNK phosphorylation [117] \\
\hline & & & $\begin{array}{l}A \beta \text {-induced neurotoxicity in } \\
\text { PC12 cells }\end{array}$ & $\begin{array}{l}\downarrow \text { ROS, LPO } \\
\downarrow \text { Caspase-3, apoptosis [118] }\end{array}$ \\
\hline & & & $\begin{array}{l}A \beta \text { memory impairment in the } \\
\text { mouse }\end{array}$ & $\begin{array}{l}\downarrow \text { Memory impairment } \\
\downarrow \text { MDA } \\
\uparrow \text { Glutathione in hippocampus } \\
\downarrow \text { IL- } 1 \beta \text {, IL-6, TNF- } \alpha[115]\end{array}$ \\
\hline & & & $\begin{array}{l}\text { Spinal cord injury model in the } \\
\text { mouse }\end{array}$ & $\begin{array}{l}\uparrow \text { Motor functions and axonal regrowth } \\
\downarrow \text { Astrogliosis } \\
\downarrow \text { IL-6, TNF- } \alpha \\
\uparrow \text { Activation of MAPK and PI3K/PKB/mTOR pathways in the } \\
\text { injured spinal cord [123] }\end{array}$ \\
\hline & & & $\begin{array}{l}\text { D-galactose-induced neurotox- } \\
\text { icity and learning and memory } \\
\text { impairment in the mouse }\end{array}$ & $\begin{array}{l}\text { Improvement of memory } \\
\uparrow \text { SOD, CAT, GPx, and GR } \\
\downarrow \text { MDA, caspase-3 } \\
\uparrow \text { Neural growth-associated protein GAP43 [119] }\end{array}$ \\
\hline & & & Model of aging mice (C57BL/6) & $\begin{array}{l}\uparrow \text { SIRT1 and SIRT-6 } \\
\text { Enhancement of } \alpha \text {-Klotho and PGC proteins levels [120] }\end{array}$ \\
\hline & & & $\begin{array}{l}\text { Ellman's assays for evaluating ace- } \\
\text { tylcholinesterase and/or butyryl- } \\
\text { cholinesterase inhibitory activity }\end{array}$ & $\downarrow$ Butyrylcholinesterase [121] \\
\hline & & & MPTP-induced PD in mouse & $\begin{array}{l}\text { Improvement of behavioral deficits } \\
\uparrow \text { Dopamine } \\
\uparrow \text { Dopaminergic neurons }[122]\end{array}$ \\
\hline & & & $\begin{array}{l}\text { High-fat diet-induced cognitive } \\
\text { impairment in C57/BL6] mouse }\end{array}$ & $\begin{array}{l}\text { Improvement of behavioral performance } \\
\downarrow \text { Endoplasmic reticulum stress and IKK } / \text { /NF-KB-mediated } \\
\text { inflammatory signaling } \\
\uparrow \text { Insulin signaling and PI3K/Akt/mTOR pathway } \\
\uparrow \text { Memory-related protein expression in the hippocampus [124] }\end{array}$ \\
\hline & & & $\begin{array}{l}\text { Traumatic brain injury-induced } \\
\text { cerebral ischemia in wild-type } \\
\text { (WT) and Nrf2(-/-) mouse }\end{array}$ & $\begin{array}{l}\downarrow \text { Brain edema and the neurological insufficiencies } \\
\uparrow \text { Nuclear translocation of Nrf2 protein } \\
\uparrow \text { Expression of NQO1 and HO1 } \\
\uparrow \text { Expression of AKT } \\
\text { Involvement of Nrf2-ARE signaling pathway } \\
\text { No effect on Nrf2(-/-) mice [126] }\end{array}$ \\
\hline & & & $\begin{array}{l}\text { Endovascular puncture model } \\
\text { of subarachnoid hemorrhage }\end{array}$ & $\begin{array}{l}\downarrow \text { Expressions of TLR4 pathway-related agents, such as ICAM-1, } \\
\text { TLR4, NF-KB, P65, IL- } 1 \beta \text {, TNF- } \alpha \text {, IL-6, iNOS, and MMP-9 } \\
\downarrow \text { Apoptosis [127] }\end{array}$ \\
\hline & & & $\begin{array}{l}\text { MCAO and reperfusion model } \\
\text { in rats }\end{array}$ & $\begin{array}{l}\text { Improvement in neurological deficit score } \\
\downarrow \text { Infarct volume } \\
\uparrow \text { Intact neurons } \\
\uparrow \text { PPARy protein and PPAR } y \text {-positive cells } \\
\downarrow \text { Protein levels of MMP2, MMP9, and activated MAPKs } \\
\uparrow \text { TIMP1 [128] }\end{array}$ \\
\hline & & & $\begin{array}{l}\text { Pentylenetetrazole-induced } \\
\text { seizures in the mouse }\end{array}$ & $\begin{array}{l}\text { Positive modulation of } \alpha 1 \beta 2 \gamma 2 \text { L GABA-A receptors Anticonvul- } \\
\text { sant, antidepressant, and anxiolytic activities [129] }\end{array}$ \\
\hline & & & $\begin{array}{l}\text { Pentobarbital-mediated sleep- } \\
\text { ing model in the mouse }\end{array}$ & $\begin{array}{l}\text { Enhances sleep duration through GABA-A receptor activation } \\
\text { [130] }\end{array}$ \\
\hline
\end{tabular}


- Table 2 Continued

\begin{tabular}{|c|c|c|c|c|}
\hline $\begin{array}{l}\text { Scientific } \\
\text { name }\end{array}$ & Plant parts [22] & $\begin{array}{l}\text { Constit- } \\
\text { uents }\end{array}$ & Experimental model & Observation/mechanism \\
\hline P. lentiscus & Resin & \multirow{6}{*}{$\begin{array}{l}\text { Oleanolic } \\
\text { acid }\end{array}$} & \multirow{2}{*}{$\begin{array}{l}\text { Cobalt chloride-induced focal } \\
\text { cortical hypoxia in rats }\end{array}$} & $\downarrow$ Neuronal degeneration and cytoskeleton changes \\
\hline P. terebinthus & Resin & & & $\begin{array}{l}\downarrow \text { Astroglial and microglial reaction } \\
\uparrow \text { Brain tissue recovery [112] }\end{array}$ \\
\hline \multirow{4}{*}{ P. atlantica } & \multirow[t]{4}{*}{ Resin } & & Neural stem cells & $\begin{array}{l}\uparrow \text { Proliferation and neural differentiation } \\
\uparrow \text { MAP2 expression } \\
\downarrow \text { Nestin } \\
\uparrow \text { Phosphorylation of GSK3 } \beta \text { at Ser9 and expression of active } \\
\text { forms of } \beta \text {-catenin [111] }\end{array}$ \\
\hline & & & $\begin{array}{l}\text { 6-OHDA induced Parkinsonian } \\
\text { in rats } \\
\text { 6-OHDA-induced intracellular } \\
\text { ROS in PC12 }\end{array}$ & $\begin{array}{l}\downarrow \text { Microglial activation } \\
\text { Improved motor symptoms } \\
\uparrow \text { Striatal dopamine } \\
\downarrow \text { Amount of intracellular ROS in PC12 cells [110] }\end{array}$ \\
\hline & & & $\begin{array}{l}\text { Experimental mouse model } \\
\text { of MS } \\
\text { (experimental autoimmune } \\
\text { encephalomyelitis) }\end{array}$ & $\begin{array}{l}\downarrow \text { Encephalomyelitis } \\
\downarrow \text { Activation of microglial cells, BBB disruption and infiltration of } \\
\text { inflammatory cells within the CNS } \\
\downarrow \text { Proinflammatory cytokines and chemokines } \\
\uparrow \text { Anti-inflammatory ones (modulatory role in Th1/Th2 polariza- } \\
\text { tion) } \\
\downarrow \text { Anti-MOG antibodies [106] }\end{array}$ \\
\hline & & & $\begin{array}{l}\text { SAH induction by a standard } \\
\text { intravascular puncture model } \\
\text { in rats }\end{array}$ & $\begin{array}{l}\downarrow \text { Permeability of BBB } \\
\downarrow \text { Brain edema by protein expression of T Js and Als } \\
\downarrow \text { SAH grades } \\
\uparrow \text { Protein expression of HO- } 1 \\
\downarrow \text { Upregulation of VEGF and the phosphorylation of p38 MAPK, } \\
\downarrow \text { p38MAPK/VEGF/Src signaling pathway [107] }\end{array}$ \\
\hline $\begin{array}{l}\text { P. integerri- } \\
\text { ma }\end{array}$ & Bark & $\begin{array}{l}\text { Pistagre- } \\
\text { mic acid }\end{array}$ & $\begin{array}{l}\text { In vitro } \beta \text {-secretase, } A C h E \text {, and } \\
\text { butyrylcholinesterase inhibition } \\
\text { assay }\end{array}$ & $\begin{array}{l}\downarrow \beta \text {-secretase } \\
\text { No obvious AChE activity [131] }\end{array}$ \\
\hline P. vera & Seed and skin & \multirow[t]{5}{*}{ Gallic acid } & $\begin{array}{l}\text { Oxidative stress induced with } \\
6-\mathrm{OHDA} \text { in PD model in rats }\end{array}$ & $\begin{array}{l}\uparrow \text { Passive avoidance memory, total thiol, and GPx contents } \\
\downarrow \text { MDA in the hippocampus and striatum [144] }\end{array}$ \\
\hline P. lentiscus & $\begin{array}{l}\text { Leaf, } \\
\text { fruit }\end{array}$ & & $\begin{array}{l}A \beta \text {-induced toxicity in neuronal } \\
\text { cells }\end{array}$ & $\begin{array}{l}\downarrow \text { NF-kB } \\
\downarrow \text { Cytokine production in microglia cells }\end{array}$ \\
\hline \multirow[t]{3}{*}{ P. atlantica } & \multirow[t]{3}{*}{$\begin{array}{l}\text { Gall, } \\
\text { leaf }\end{array}$} & & $\begin{array}{l}\text { A } \beta \text {-induced cognitive dysfunc- } \\
\text { tion in mouse }\end{array}$ & $\begin{array}{l}\downarrow \text { Neuronal cell death } \\
\downarrow \text { Expression of cytokines } \\
\downarrow \text { NF-kB acetylation } \\
\text { Improvement of cognitive dysfunction [141] }\end{array}$ \\
\hline & & & $\begin{array}{l}\text { Traumatic brain injury in rat } \\
\text { (Marmarou's method) }\end{array}$ & $\begin{array}{l}\text { Improvement of neurological score, memory, and long-term } \\
\text { potentiation from hippocampal dentate gyrus } \\
\downarrow \text { Brain lipid peroxidation and cerebral proinflammatory cytokines } \\
\text { [145] }\end{array}$ \\
\hline & & & $\begin{array}{l}\text { Glutamate-induced neurotoxic- } \\
\text { ity in primary rat cortex neurons } \\
\text { culture }\end{array}$ & $\begin{array}{l}\downarrow \text { Neurotoxicity } \\
\downarrow \text { Cortex neurons antioxidant profile } \\
\downarrow \text { Proinflammatory cytokine } \\
\text { Maintenance of Ca2+ homeostasis, IGF-1 expression [146] }\end{array}$ \\
\hline
\end{tabular}

cont.

as COX-2 in brain tissue [83]. The role of CB2 was revealed in another study as well. In a mouse model of $A D, \beta$-caryophyllene ameliorated the Alzheimer-like phenotype in mice with reducing $A \beta$ in brain tissue. It also reduced astrogliosis and microglial activation as well as the levels of COX-2 and proinflammatory cytokines in the cerebral cortex; its protective effect was associated to $C B 2$ receptor activation and the PPARy pathway [84]. The cytoprotective effect of this sesquiterpene has also been indicated to be mediated through the amelioration of cellular antioxidant re- sponses via Nrf2 activation, which is, in part, dependent on CB2R activation [85]. Similar results were obtained after evaluating the effect of $\beta$-caryophyllene against lipopolysaccharides-induced oligodendrocyte toxicity in vitro. There were remarkable correlations between $\beta$-caryophyllene concentration and selective modulation of CB2, Nrf2, sphingomyelinase (SMase), and PPARy c pathways [86]. Moreover, $\beta$-caryophyllene was shown to alleviate high-fat/ fructose-diet-induced neurobehavioral changes in rats. The role of PPAR-y and CB2R in the anxiolytic, antioxidant, and anti-inflam- 
- Table 2 Continued

\begin{tabular}{|c|c|c|c|c|}
\hline $\begin{array}{l}\text { Scientific } \\
\text { name }\end{array}$ & Plant parts [22] & $\begin{array}{l}\text { Constit- } \\
\text { uents }\end{array}$ & Experimental model & Observation/mechanism \\
\hline P. vera & $\begin{array}{l}\text { Seed, } \\
\text { skin }\end{array}$ & Catechin & $\begin{array}{l}\text { Doxorubicin-induced memory } \\
\text { deficit in Wistar rats } \\
\text { Doxorubicin-induced neurotox- } \\
\text { icity in IMR-32 neuroblastoma } \\
\text { cells }\end{array}$ & $\begin{array}{l}\uparrow \text { Viability of undifferentiated IMR-32 cells } \\
\uparrow \text { Neurite length of differentiated cells } \\
\downarrow \text { OS } \\
\downarrow \text { Neuroinflammation } \\
\downarrow \text { AChE }[152]\end{array}$ \\
\hline \multirow[t]{5}{*}{ P. lentiscus } & \multirow[t]{2}{*}{ Leaf } & & $\begin{array}{l}A \beta \text {-induced } B A C E-1 \text { upregulation } \\
\text { in neuronal culture }\end{array}$ & $\begin{array}{l}\downarrow \text { ROS and beta-sheet structure formation } \\
\downarrow A \beta \text {-induced BACE-1 upregulation [142] }\end{array}$ \\
\hline & & & $\begin{array}{l}\text { Traumatic brain injury model in } \\
\text { rats }\end{array}$ & $\begin{array}{l}\text { Protection of BBB integrity } \\
\uparrow \text { Junction proteins } \\
\downarrow \text { Local inflammatory reactions [153] }\end{array}$ \\
\hline & & & $\begin{array}{l}\text { Streptozotocin-induced diabetes } \\
\text { in rats }\end{array}$ & $\begin{array}{l}\text { Improvement of alternation score and retention and recall in pas- } \\
\text { sive avoidance test } \\
\downarrow \text { MDA and nitrite [155] }\end{array}$ \\
\hline & & & $\begin{array}{l}\text { Streptozotocin-induced model } \\
\text { of dementia in rats }\end{array}$ & $\begin{array}{l}\text { Improvement of cognitive deficit, S100B content and secretion, } \\
\text { AChE activity, GPx activity, NO metabolites, and ROS content } \\
\text { [156] }\end{array}$ \\
\hline & & & MPTP-induced PD in mice & $\begin{array}{l}\text { Prevention of neurotoxicity } \\
\downarrow \text { Dopaminergic neuron loss in substantia nigra [157] }\end{array}$ \\
\hline P. vera & $\begin{array}{l}\text { Skin, } \\
\text { nuts }\end{array}$ & $\begin{array}{l}\text { Cyanidin- } \\
\text { 3-O-glu- } \\
\text { coside }\end{array}$ & $\begin{array}{l}\text { A } \beta \text {-induced neurotoxicity } \\
\text { in a human neuronal cell line } \\
\text { (SH-SY5Y). }\end{array}$ & $\begin{array}{l}\downarrow \text { Apoptosis and Necrosis } \\
\downarrow \text { A } \beta \text { oligomer binding to plasma membrane, } \\
\downarrow \text { Membrane integrity loss [158] } \\
\text { cont. }\end{array}$ \\
\hline
\end{tabular}

matory effects of $\beta$-caryophyllene was proven in this study as well. Its memory-enhancing and antidepressant effects are probably mediated via CB2R, mainly by the upregulation of BDNF and peroxisome proliferator-activated receptor gamma coactivator- $1 \alpha$ (PGC-1 $\alpha$ ) [87].

$\beta$-Caryophyllene might exert its neuroprotective effects in PD via multiple mechanisms as well. It showed an ameliorative effect in a 1-methyl-4-phenyl-1,2,3,6-tetrahydropyridine (MPTP)-induced murine model of PD by decreasing the levels of inflammatory cytokines in the nigrostriatal system and involvement of the CB2 receptors [88]. In a rotenone-induced oxidative stress/neuroinflammation rat model of $\mathrm{PD}, \beta$-caryophyllene reversed the loss of dopaminergic neurons and decreased microglia and astrocyte activation, as evidenced by reduced ionized calcium-binding adaptor molecule-1(Iba1) and glial fibrillary acidic protein (GFAP) expression. Attenuation of proinflammatory cytokines and inflammatory mediators such as COX-2 and inducible nitric oxide synthase (iNOS), restoration of antioxidant enzymes, and inhibition of lipid peroxidation and glutathione depletion were also reported [89].

It has been reported that $\beta$-caryophyllene alleviates cerebral ischemia injury through its potent neuroprotective activity in vivo via inhibiting neuronal death and inflammatory responses [90]. It has been shown to reduce necroptotic cell death via the downregulation of receptor-interaction protein kinase (RIPK)1, RIPK3, and mixed lineage kinase domain like pseudokinase (MLKL) expression in vivo, as well as alleviation of inflammation through inhibiting the high-mobility group box 1(HMGB1)-toll-like receptor (TLR4) signaling pathway [91]. This compound also reduced the mRNA expression of iNOS, IL-1 $\beta$, IL-6, and COX-2 in microglial cells, and decreased the levels of $\mathrm{NO}$ and prostaglandin E2 [90]. In another study, Nrf2/HO-1 was introduced as an involved pathway in $\beta$ caryophyllene protection against cerebral ischemia injury in vivo [92]. Chang et al. [93] investigated the neuroprotective effect of different terpenoids on human neuroblastoma SH-SY5Y, in vitro, by using a simulated ischemia model, and trans-caryophyllene was identified as the most potent neuroprotective agent. In the mentioned study, terpinen-4-ol, one of the other terpenes of the Pistacia genus, was also found as a neuroprotective substance.

\section{Myrcene}

$\beta$-Myrcene is a monoterpene that forms about $40 \%$ of the essential oil of $P$. lentiscus leaves [94] and has been notably (41\%) identified in the methanolic extract of $P$. atlantica fruits [95]. In an animal model of cerebral ischemia/reperfusion-induced oxidative stress, myrcene treatment protected against neurotoxicity, which occurred via an increase in TBARS formation and a decrease in the antioxidant defense systems, including glutathione (GSH), CAT, GPx, and SOD. Myrcene also eliminated the histopathological damage and apoptosis in brain tissue [96].

\section{Limonene}

Limonene, another monoterpene, which has a cyclic structure, forms about $10 \%$ of essential oil obtained from $P$. lentiscus leaves [94], and $4-5 \%$ of the methanolic extract of $P$. atlantica fruits [95]. Evaluation of the effects of $\mathrm{d}$-Limonene on a PC12 cellular model of corticosterone-induced neurotoxicity showed that it has antioxidant and anti-inflammatory effects via decreasing the levels of MDA and NO, activities of NADPH oxidase, and expression of 
- Table 2 Continued

\begin{tabular}{|c|c|c|c|c|}
\hline $\begin{array}{l}\text { Scientific } \\
\text { name }\end{array}$ & Plant parts [22] & $\begin{array}{l}\text { Constit- } \\
\text { uents }\end{array}$ & Experimental model & Observation/mechanism \\
\hline \multirow[t]{10}{*}{$P$. vera } & \multirow[t]{10}{*}{ Seed, skin } & \multirow[t]{10}{*}{ Quercetin } & $\begin{array}{l}\text { Radiation-induced brain injury } \\
\text { in rats }\end{array}$ & $\begin{array}{l}\downarrow \text { Cellular degeneration and infiltration parameters } \\
\downarrow \text { OS [171] }\end{array}$ \\
\hline & & & MPTP-induced PD in mice & $\begin{array}{l}\text { Improvement of the motor balance and coordination } \\
\uparrow \text { Activities of GPx, SOD, and Na/K-ATPase, AChE, dopamine } \\
\downarrow 4 \text {-Hydroxy-2-nonenal immunoreactivity in the striatum of } \\
\text { brains [204] }\end{array}$ \\
\hline & & & $\begin{array}{l}\text { Aged triple transgenic AD model } \\
\text { in mice }\end{array}$ & $\begin{array}{l}\downarrow \text { Extracellular } \beta \text {-amyloidosis, tauopathy, astrogliosis and micro- } \\
\text { gliosis } \\
\downarrow \text { PHF, } \beta \text { A } 1-40 \text { and } \beta \text { A } 1-42 \text { levels ‘ } \\
\downarrow \text { BACE1-mediated cleavage of APP antibody } \\
\text { Improvement of performance in learning and spatial memory } \\
{[162]}\end{array}$ \\
\hline & & & $\begin{array}{l}\text { Cadmium-induced memory } \\
\text { impairment and anxiogenic- } \\
\text { like behavior in rats }\end{array}$ & $\begin{array}{l}\downarrow \text { Impaired memory and anxiogenic effect } \\
\uparrow \mathrm{Na} / \mathrm{K}-\mathrm{ATP} \text { ase activity } \\
\downarrow \text { ROS, TBARS, protein carbonyl content, dsDNA fractions } \\
\uparrow \mathrm{T}-\mathrm{SH}, \mathrm{GSH} \text {, and GR activities and the rise of GST activity } \\
\downarrow \text { AChE activity [163] }\end{array}$ \\
\hline & & & $\begin{array}{l}\mathrm{A} \beta(1-42) \text {-induced oxidative cell } \\
\text { toxicity in cultured neurons }\end{array}$ & $\begin{array}{l}\downarrow A \beta(1-42) \text {-induced cytotoxicity, protein oxidation, lipid peroxi- } \\
\text { dation and apoptosis [164] }\end{array}$ \\
\hline & & & $\begin{array}{l}\text { Mouse model of } A D \text {, } \\
\text { hippocampal neuronal culture }\end{array}$ & $\begin{array}{l}\uparrow \text { Cell proliferation in the hippocampal neurons } \\
\uparrow \text { Neurogenesis, synaptogenesis and cell proliferation } \\
\downarrow \text { A } \beta \text {-induced synaptic loss } \\
\uparrow \text { Phosphorylation of CREB } \\
\uparrow \text { BDNF } \\
\uparrow \text { Dendritic processes in hippocampal neurons [166] }\end{array}$ \\
\hline & & & $\begin{array}{l}\text { Perphenazine and reserpine- } \\
\text { induced catalepsy in rats }\end{array}$ & $\begin{array}{l}\downarrow \text { Catalepsy } \\
\downarrow \text { Activity of COMT and MAO } \\
\uparrow \text { Bioavailability of L-dopa in the brain [168] }\end{array}$ \\
\hline & & & $\begin{array}{l}\text { MPPT-induced oxidative stress } \\
\text { in PC12 cells }\end{array}$ & $\begin{array}{l}\downarrow \text { Apoptotic death } \\
\downarrow \text { Phosphorylation of STAT } \\
\text { Modulation of mRNA levels and protein expression of Bax and Bcl-2 } \\
\text { Release of cytochrome c and nuclear translocation of the AIF [169] }\end{array}$ \\
\hline & & & $\begin{array}{l}\text { Rotenone-induced hemi-Parkin- } \\
\text { son in rats }\end{array}$ & $\begin{array}{l}\downarrow \text { Amphetamine- or apomorphine-induced unilateral rotations } \\
\downarrow \text { Rotenone-induced loss in striatal dopamine, and nigral oxidized } \\
\downarrow \text { Glutathione } \\
\uparrow \text { CAT and SOD } \\
\uparrow \text { Mitochondrial complex-I activity [170] }\end{array}$ \\
\hline & & & $\begin{array}{l}\text { Transient bilateral common } \\
\text { carotid artery occlusion and } \\
\text { reperfusion in rats }\end{array}$ & $\begin{array}{l}\downarrow \text { Microvascular permeability, leukocyte adhesion and ROS } \\
\text { Protection of capillary perfusion. } \\
\downarrow \text { Arteriolar dilation [172] }\end{array}$ \\
\hline
\end{tabular}

6-OHDA: 6-Hydroxydopamine; $\Delta \psi_{\mathrm{m}}$ : Mitochondrial membrane potential; AChE: Acetylcholinesterase; AD: Alzheimer's disease; AlF: Apoptosis-inducing factor; Akt: Protein kinase B; AMPK $\alpha$ : AMP-activated protein kinase; BAX: BCL2 associated X; BBB: Blood-brain barrier; Bcl-2: B-cell lymphoma 2; BDNF: Brainderived neurotrophic factor; CAT: Catalase; CAV: Caveolin; CB2: Cannabinoid receptor type 2; CI-R: Cerebral ischemia-reperfusion; COMT: catechol-Omethyltransferase; COX2: Cyclooxygenase 2; CRBE: Cyclic-AMP response element binding protein; DHE: Dihydroethidium; DMPD: N,N-dimethyl-p-phenylenediamine; ERK1: Extracellular signal-regulated kinases 1; GFAP: Glial fibrillary acidic protein; GPx: glutathione peroxidase; GR: glutathione reductase; GSH: Glutathione; GSK3 $\beta$ : Glycogen synthase kinase 3 $\beta$; HMGB-1: High-mobility group box 1. HO-1: heme-oxygenase 1; Iba-1: Ionized calcium binding adaptor molecule 1; ICAM-1: Intercellular adhesion molecule-1; IGF-1: Insulin-like growth factor 1; IL-1 $\beta$ : Interleukin 1 beta; IKK: IKB kinase $\beta$; JNK: c-Jun N-terminal kinases; MAP-2: Microtubule-associated protein 2; MAPK: Mitogen-activated protein kinase; MCP-1: Monocyte chemoattractant protein-1; MCAO: Middle cerebral artery occlusion; MDA: Malondialdehyde; MLKL: Mixed lineage kinase domain-like pseudokinase; MMP: Matrix metalloproteinase; MOG: Myelin-oligodendrocyte glycoprotein. MPTP: 1-Methyl-4-phenyl-1,2,3,6-tetrahydropyridine; NADPH: Nicotinamide adenine dinucleotide phosphate; mTOR: Mammalian target of rapamycin; NF-кB: Nuclear factor kappa B; NO: Nitric oxide; NOS2: Nitric oxide synthase 2; NPT: Nonprotein thiols content; NQO1: NAD(P)H quinone dehydrogenase 1; Nrf2: Nuclear factor erythroid 2-related factor 2; OGD/R: Oxygen glucose deprivation/reoxygenation; OS: Oxidative stress; PC12: pheochromocytoma cells; PD: Parkinson's disease; PGC-1 $\alpha$ : peroxisome proliferator-activated receptor gamma coactivator 1 alpha; PGE2: Prostaglandin E2; PHF: Paired helical filament; PI3K: phosphoinositide 3-kinase; PKB: protein kinase B: PPAR: Peroxisome proliferator-activated receptors; PTZ: pentylenetetrazol; RIPK: Receptor-interaction protein kinase; ROS: Reactive oxygen species; SAH: Subarachnoid hemorrhage; Ser9: Phospho-GSK-3b $\beta$; SIRT: Sirtuins; SOD: Superoxide dismutase; TBAR: Thiobarbituric acid-reactive. TIMP1: Tissue inhibitor of metalloproteinases; TLR: Toll-like receptor; TNF- $\alpha$ : Tumor necrosis factor- $\alpha$; TUNEL: Terminal deoxynucleotidyl transferase dUTP nick end labeling; VGEF: Vascular endothelial growth factor; WT: Wild type 
proinflammatory markers such as iNOS, COX-2, IL-6, IL- $1 \beta$, and TNF- $\alpha$. It also reduced the expression of BCL2-associated $X$ protein (Bax), cleaved caspase-3, and increased antiapoptotic protein $\mathrm{Bcl}-$ 2. d-Limonene significantly activated AMP-activated protein kinase $(\mathrm{AMPK} \alpha)$ and inhibited nuclear translocation of NF- $\kappa \mathrm{B}$ through upregulating sirtuin (SIRT)1 [97]. In an animal model of high anxiety induced by chronic immobilization stress, limonene reduced stress-induced damage in CA1 pyramidal neurons and reversed adverse effects of anxiety [98]. Moreover, impairment in cognitive and memory functions following cerebral ischemia was reversed by $D$-limonene in rats. It decreased the cerebral infarct size following stroke, along with decreasing mRNA expression of $\mathrm{IL}-1 \beta$, monocyte chemoattractant protein-1 (MCP-1), and COX-2, and increasing the activities of antioxidant enzymes in rats following stroke [99]. In another in vivo study, administration of s-limonene attenuated the memory deficits resulting from scopolamine. It improved dopamine reduction induced by scopolamine [100]. s-Limonene has shown also AChE inhibitory activity in vitro [100].

\section{Triterpenoids}

Some triterpenoid derivatives have recently been identified as potential neuroprotective agents with their ability to protect the brain against neurodegenerative and neuroinflammatory processes $[101,102]$. Some triterpenes such as oleanolic acid (OA), masticadienonic acid, morolic acid, ursonic acid [22], and ursolic acid (UA) $[103,104]$ have been identified in different Pistachia species, and pistagremic acid has been isolated from galls of $P$. integerrima [22].

\section{Oleanolic acid}

$\mathrm{OA}$ is a pentacyclic triterpenoid compound with a widespread occurrence either as a free acid or as an aglycone precursor for triterpenoid saponins throughout the plant kingdom. Besides its anti-inflammatory and antioxidant activities, OA has been shown to possess neuroprotective effects in several studies [105]. In an experimental mice model of multiple sclerosis, OA inhibited the development of autoimmune encephalomyelitis (EAE), and reduced activation of microglial cells, blood-brain barrier (BBB) disruption, and infiltration of inflammatory cells within the CNS [106]. Its effect in protecting the integrity of the BBB has been shown to be associated with an increase in protein expression of tight and adherent junctions in a rat model of subarachnoid hemorrhage. This compound also suppressed the p38MAPK/VEGF/Src signaling pathway, which is involved in BBB disruption [107]. In a mice model of MS, OA also showed a modulatory role in $\mathrm{T}$ helper cell polarization [106]. EAE mice treated with OA had a decrease in the cytokine osteopontin level and TNF- $\alpha$ in CNS tissue. Moreover, EAE mice treated with OA had lower levels of anti-myelin-oligodendrocyte glycoprotein (anti-MOG) antibodies than untreated animals [106]. In vitro, OA decreased the inflammatory stimuli-induced proliferative response, phagocytic properties, and synthesis of proinflammatory mediators in microglia; it also inhibited extracellular signal-regulated kinases (ERK) and ribosomal protein S6 (rS6) phosphorylation as key factors of the MAPK and mammalian target of rapamycin (mTOR) pathways, which play a crucial role in the regulation of cell growth and proliferation [108].
As a beneficial natural product in PD, OA ameliorated forelimb use asymmetry in a 6-OHDA-induced PD rat model and inhibited the reduction of dopamine in the striatum of PD animals. It also decreased membrane depolarization and attenuated mitochondrial apoptosis [109]. OA exerted its neuroprotective effects in 6OHDA-induced PD in rats by attenuating microglial activation [110]. In vitro, it inhibited the accumulation of intracellular ROS in PC12 cells, resulted in promoting cell survival [110]. In another study, migration, proliferation, and differentiation of neural stem cells (NSCs) were elevated by OA. The mechanism of action was determined as suppressing glycogen synthase kinase $3 \beta$ (GSK3 $\beta$ ) activity, which has a role in peripheral and CNS inflammation in various neurological disorders [111].

Pretreatment of rats with OA before focal cortical hypoxia induced by brain injection of cobalt chloride resulted in a reduction of neuronal damage and glial reaction as well as recovery of brain tissue after injury [112]. OA mitigated cognitive deficits in a rat model of $A \beta$-induced $A D$. Related to this, in a model of beta-amyloid-stimulated astrocytes, OA ameliorated primary neuron death and neuroinflammation (via inhibiting transcription and secretion of IL-6, TNF- $\alpha$, and IL-1 $\beta$ ) in secretory phopholipase type A2 (sPLA2)-IIA-mediated calcium signals [113].

\section{Ursolic acid}

UA as another naturally derived pentacyclic triterpene acid derives from a hydride of an ursane. It is widely found in fruits, spices, and medicinal herbs [114] such as in the Pistacia genus [103,104]. Several studies have evaluated the neuroprotective effects of this compound against $A \beta$ to show the therapeutic potential of this phytochemical for $A D$. It has been reported that $A \beta$-induced memory and learning deficits in mice were reversed by UA, along with a decrease/increase in MDA/glutathione levels in the mouse hippocampus. Besides its antioxidant effect, UA also reduced the levels of inflammatory markers (IL-1 $\beta$, IL-6, and TNF- $\alpha$ ) [115]. In vitro, UA was also shown to attenuate $A \beta$-induced neurotoxicity in PC12 neuronal cells through modulation of the NF- $\kappa$ B signaling pathway [116]. In these cells, it has also been shown to inhibit the $A \beta$-induced expression of iNOS and COX- 2 through inhibition of $\mathrm{NF}-\mathrm{KB}$ activity, along with reduced ERK1/2, p-38, and Jun N-terminal kinases (JNK) phosphorylation [117]. Moreover, UA reversed the increase in ROS, LPO, and apoptosis induced by $A \beta$ via inhibiting caspase- 3 activity [118].

Treatment with UA in aged mice subjected to D-galactoseinduced neurotoxicity resulted in improved memory as well as elevated the levels of antioxidant enzymes SOD, CAT, GPx, and glutathione reductase (GR) and decreased the level of MDA. In addition, the activation of caspase- 3 was inhibited by UA, while the level of neural growth-associated protein GAP43 was elevated [119]. Anti-aging effects of UA might also be considered through increasing the levels of anti-aging biomarkers such as SIRT1, SIRT6, $\alpha$-Klotho, and PGC- $1 \beta$ protein [120].

UA has also been reported as an AChE inhibitor, which is one of the characterized targets in a therapeutic approach to AD. The synthetic hydroxyl-propinyl derivatives of UA were shown as more potent AChE/butyrylcholinesterase inhibitors [121].

In an experimental PD mouse model, UA was shown to protect dopaminergic neurons in MPTP-intoxicated mice. It also improved 
behavioral deficits and restored the altered dopamine level. UA mitigated the MPTP-induced increase of MDA and NO levels [122].

UA has been shown to mimic the human natural killer (HNK)-1 and promote the regaining of motor functions and axonal regrowth in mice with a spinal cord injury via activation of MAPK and $\mathrm{PI3K} / \mathrm{Akt} / \mathrm{mTOR}$ pathways. It also reduced astrogliosis and levels of proinflammatory markers (IL- 6 and TNF- $\alpha$ ) in the acute phase of inflammation in injured spinal cords [123]. Additionally, UA administration has been indicated to reverse high-fat diet-induced cognitive impairment via inhibition of endoplasmic reticulum stress and NF-KB signaling and activating the PI3K/Akt/mTOR pathway in the mouse hippocampus [124].

UA treatment in mouse models of cerebral ischemia [125] and traumatic brain injury [126] led to a decrease in oxidative stress $[125,126]$ by enhancing the expression of antioxidant enzymes (NQO1 and HO1) as well as Akt, as an Nrf2 upstream factor, suggesting a possible mechanism via activation of the Nrf2-ARE pathway [126]. It also decreased inflammatory factors (TLR4 and NF$\kappa \mathrm{B})$ after stroke in the mouse brain [125]. In a subarachnoid hemorrhage rat model, UA treatment reduced early brain injury via reducing apoptosis and suppressing TLR4-mediated inflammatory factors, such as intercellular adhesion molecule-1 (ICAM-1), TLR4, NF- $\kappa$ B, IL-1 $\beta$, TNF- $\alpha$, IL-6, iNOS, and matrix metalloproteinase (MMP)-9 [127]. It also showed neuroprotective effects as an activator of PPARs in a rat model of cerebral artery occlusion and reperfusion and modulated the metalloprotease/anti-metalloprotease balance, possibly by inhibiting the MAPK signaling pathway [128]. UA has also been shown to have anxiolytic, anticonvulsant, and antidepressant activities in mice via affecting the GABA-A receptor, especially acting on the benzodiazepine binding site of GABA receptors $[129,130]$.

\section{Pistagremic acid}

Pistagremic acid, another triterpenoid compound isolated from $P$. integerrima, was evaluated for b-secretase (BACE 1) enzyme inhibition and showed significant activity against BACE1, which plays an important role in APP (amyloid precursor protein) cleavage and subsequent formation of $A \beta 40-42$. However, the effect of pistagremic acid was selective for BACE1 and its inhibitory activity was insignificant against acetylcholinesterase and butyrylcholinesterase enzymes [131].

\section{Masticadienonic acid}

Although masticadienonic and masticadienolic acids are among specific triterpenoids identified in the resins of the Pistacia genus [22], there are limited studies on the neuroprotective activity of these natural products. In one study, these triterpenoids showed anti-inflammatory effects in vivo by preventing PMA-induced ear edema, and also the synthesis of lipooxygenase products [132]. In a recently published clinical study, Hazan et al. [133] reported the safety and tolerability of RPh201 in a phase 1, placebo-controlled, double-blinded trial in healthy subjects. RPh201 has been introduced as a botanical formulation, mainly containing masticadienonic acid and isomasticadienonic acid from mastic gum. They also reported that based on their previous in vivo studies, RPh201 promoted neurogenesis and synaptogenesis, and increased functional recovery of cognition, memory, and sensorimotor impair- ments (unpublished data) [133]. Next they designed a phase 2 clinical trial (NCT02045212) for the assessment of the effect of RPh201 in subjects with previous non-arteritic anterior ischemic optic neuropathy, which is a neurodegenerative disease resulting in vision loss. As a result, improvement in visual acuity was reported in the RPh201 group compared to placebo. The phase 3 clinical trial is in recruiting status (NCT03547206) [134].

\section{Phenolic Compounds}

\section{Gallic acid}

Gallic acid, a phenolic compound, is a well-known trihydroxybenzoic acid found abundantly in free and conjugated (hydrolysable tannins) or esterified forms in many plants [135]. Gallic acid and its derivatives have also been isolated from different Pistacia species [22]. As a polyphenolic compound in dietary and medicinal plants, its pharmacokinetic characteristics have been partially studied [136,137]. It has been shown that when $50 \mathrm{mg}$ gallic acid was orally administrated to healthy volunteers, its metabolites concentration in plasma reached $4 \mu \mathrm{M}$ and the urinary level was about $37 \%$ of the ingested amount [136]. One animal study also indicated that gallic acid exhibited slower absorption in myocardial infarcted rats than those in normal rats. However, there is still uncertainty about its pharmacokinetic profile under pathological conditions [138].

As a phytochemical with antioxidant and anti-inflammatory activities, the neuroprotective effect of gallic acid against neuroinflammation, neurodegeneration, and neurotoxicity has been reviewed in some studies $[135,139,140]$. It has been indicated that gallic acid inhibits $A \beta$-induced neurotoxicity via suppressing microglial-mediated neuroinflammation and decreasing cytokine generation and levels of NF- $\kappa$ B acetylation [141]. The ester derivative of gallic acid, epigallocatechin gallate, also plays a positive role in the modification of $A D$ through suppressing $A \beta$-induced beta-site APP cleaving enzyme-1 upregulation [142]. Furthermore, it has been shown to regulate the amyloid precursor protein and increase the transferrin receptor in H-SY5Y neuroblastoma cells. These findings seem to be related to its metal (especially iron) chelating activity [143]. Gallic acid has been demonstrated to reduce memory deficit and cerebral oxidative stress in a $6-\mathrm{OH}$ DA-induced Parkinson's disease model in rats [144]. Also, its neuroprotective effect has been shown in models of traumatic brain injury [145], and glutamate-induced neurotoxicity [146] in rats, which was due to improvement of the antioxidant profile and inhibition of proinflammatory cytokine generation $[145,146]$.

\section{Catechin}

Catechin (a flavan-3-ol) belongs to the flavonoids and is well recognized as an antioxidant [147]. Catechin isomers and their gallic acid conjugates are naturally occurring constituents in various plants [148], in which the Pistacia genus is also among them [22]. Despite their therapeutic effects, catechins have been shown with low systemic bioavailability, poor membrane permeability, and rapid metabolism. In this regard, some strategies have recently been used for their structural modifications to improve pharmacokinetic properties [149]. 
There have been several reviews to date on the neuroprotective properties of catechins, which were mostly through antioxidation and anti-inflammation effects mainly involving Nrf2 and NF-kB signaling pathways $[147,150,151]$. One in vivo study has revealed that it can improve cognitive impairment induced by doxorubicin via increasing antioxidant defense, preventing neuroinflammation, and inhibiting AChE [152]. Another study showed that catechin has neuroprotective activity in a rat model of traumatic brain injury. An anti-inflammatory effect and intervention in the self-perpetuating procedure of BBB disruption were underlying mechanisms [153]. Catechin has also been indicated to inhibit the late stages of $A \beta$-soluble aggregate growth change in the fibrillar form of $A \beta$ [154]. In streptozotocin-induced diabetes [155] and dementia [156] models in rat, catechin treatment resulted in the improvement of behavioral alternations, along with a decrease in the levels of MDA and nitrite [155], and reduction in cognitive deficit, S100B content, AChE activity, NO, and ROS content [156]. It also prevented neurotoxin-induced dopamine neuron loss in substantia nigra in a mouse model of PD [157].

\section{Cyanidin 3-O-glucoside}

Cyanidin 3-O-glucoside has also been shown to inhibit the formation of $A \beta$ oligomers in a human neuronal cell line (SH-SY5Y) [158].

\section{Quercetin}

The well-known and widespread flavonoid quercetin has frequently been reviewed as a neuroprotective polyphenol in several studies [159-161]. Various evidence showed that quercetin can exert neuroprotection, mostly via countering oxidative stress, which is known as one of the important causes of neurodegenerative conditions [161]. Also, quercetin protects neuronal cells through modifying some of the main features involved in $A D$ including $A \beta$ aggregation, and the APP cleaving enzyme (BACE1) [162], as well as AChE inhibition [163]. It has been reported that quercetin attenuated $A \beta(1-42)$-induced cytotoxicity, lipid peroxidation, and protein oxidation as well as apoptosis in primary hippocampal neuron cultures [164]; it also improved the emotional and cognitive impairments in AD models [165]. Quercetin treatment in the hippocampal neurons resulted in the elevation of neurogenesis, synaptogenesis, and cell proliferation as well as restoration of $A \beta$-induced synaptic loss. It also increased phosphorylation of the cAMP response element-binding protein (CREB) in these cells and enhanced the levels of pCREB in the mouse brain [166].

Furthermore, as a potential effective natural product in PD [167], quercetin has been shown to possess inhibitory activity on catechol-O-methyltransferase (COMT) and monoamine oxidase (MAO) enzymes, which can lead to an increase of the bioavailability of L-dopa in the brain [168]. It has been able to inhibit the phosphorylation of the signal transducer and activator of transcription (STAT) and prevent apoptosis in dopaminergic cells via the down/upregulation of $\mathrm{Bax} / \mathrm{Bcl}-2$, respectively [169]. Considering its free radical scavenging activity, quercetin also adjusted the electron transport defect of mitochondria and upregulated Complex I in a rotenone-induced rat model of PD [170]. Its protective effect in an animal model of radiation-induced brain injury was also reported through the antioxidant mechanism [171]. Moreover, quercetin decreased rat pial microvascular permeability, leuko- cyte adhesion, and ROS production during transient bilateral common carotid artery occlusion and reperfusion [172]. The neuroprotective effects of quercetin are manifested through different signaling pathways, including regulation of cytokines via Nrf2, JNK, protein kinase C, MAPK signaling cascades, and PI3K/Akt pathways [173]. Moreover, quercetin has been indicated to be effective in attenuating diabetes-induced neurodegeneration and inflammation due to inhibition of the STAT [150].

\section{Phytochemistry and Pharmacokinetics}

\section{Terpenes}

Terpenes are derived from isoprene units with five carbons, and based on the number of isoprene units, terpenes can be classified as hemiterpenes (C5), monoterpenes (C10), sesquiterpenes (C15), diterpenes (C20), sesterterpenes (C25), triterpenes (C30), and tetraterpenes (C40) [174]. Triterpenoids are mostly found as tetra- or penta-cyclic structures, but acyclic, mono-, bi-, tri- and hexa-cyclic triterpenoids also exist. The pentacyclic triterpenes are divided into three major classes: lupane, oleanane, and ursane [175].

Various pharmacological activities of terpenes have been reported so far, but the clinical relevance of these effects depends on the systemic availability of these natural compounds. However, for monoterpenoid compounds, more pharmacokinetic data in humans are needed. In addition, based on studies supporting the effects of volatile compounds of essential oils on cognitive function via aromatherapy, it is important to evaluate their absorption through the skin, or following inhalation, and crossing the BBB $[176,177] .\left(^{+}\right)$- $\alpha$-Pinene, $(+)$-limonene, and $(-)$-linalool have been shown to be transported to the brain in different amounts following inhalation in mice, indicating that even their low concentrations are capable of exerting effects on the brain [177]. Bicyclic monoterpenoids easily transport to the brain both by inhalation and through blood. $\beta$-Caryophyllene is a volatile bicyclic sesquiterpene with extensive biological activities, occurring in the essential oil of numerous plants. However, its poor water solubility and physiochemical sensitivity might decrease its bioavailability. These potential complications have resulted in the use of various drug delivery systems for $\beta$-caryophyllene, mostly including inclusion complexes and nonoemulsions, which have been shown to improve its oral bioavailability and neuropharmacological activity in vivo [178].

Various studies on the bioavailability of pentacyclic triterpenes showed that several factors can affect the oral bioavailability of these natural products. Their bioavailability can be improved by increasing the low solubility in the gastrointestinal fluid for better absorption, and, in some cases, by inhibiting their metabolism. It has been shown that high-fat meals enhance triterpene absorption [179]. As a triterpenoid compound, oral administration of $\mathrm{OA}$ in rats resulted in low gastrointestinal absorption and hepatic microsomal metabolism [174]. UA is also known to be almost insoluble in water, with a low oral bioavailability. These compounds require some modifications to improve their bioavailability. For example, in the form of self-micro/nano emulsion, the intestinal absorption and bioavailability of UA/OA has been improved. After 
absorption, $\mathrm{OA}$ is transported to the liver where it is converted to its glucuronic acid conjugate. Conjugated OA is transported via the bile to the gut. Then it is hydrolyzed to OA again. UA is mostly distributed in the liver, spleen, stomach, and kidney after intravenous administration, and is rapidly removed by metabolism and in small amounts through the excretion of the kidneys [180].

\section{Phenolic compounds}

Studies revealed that (poly)phenols and their metabolites can enter the brain at detectable levels in mammals, which supports their direct neurological action [181]. As a hydroxybenzoic acid, gallic acid has been shown to be effectively accumulated in the brain. It has been detected in trace amounts in the mouse brain after repeated oral administration of a polyphenolic grape extract [182]. Some studies focusing on the bioavailability of gallic acid in humans also showed that compared with other polyphenols, this compound is relatively well absorbed [182].

The chemical structures of flavonoids are based on a diphenylpropane (C6-C3C6) skeleton with two aromatic rings as part of a six-member heterocyclic ring. These compounds can be divided into three classes, including flavonoids, neoflavonoids, and isoflavonoids, based on the connection of the aromatic ring to the heterocyclic ring. Depending on the degree of oxidation and saturation in the heterocyclic C-ring, flavonoids might be divided into different subclasses and minor subclasses $[183,184]$. Among different dietary flavonoids, flavanols, flavanones, and flavonol glycosides have intermediate rates of absorption and bioavailability, while proanthocyanidins, flavanol gallates, and anthocyanins have the lowest absorption [183]. Dietary flavonoids occur mainly as glycosides and need to undergo enzymatic deglycosylation before absorption. The only subclass of flavonoids that could be present in the non-glycosylated form in the diet are flavan-3-ols [i.e., $(+)$-catechin, (-)-epicatechin], which are absorbed mainly in the small intestine [184]. -(-)Epicatechin and quercetin as flavan-3ol and flavonol compounds, respectively, enter the circulatory system after ingestion, in only trace amounts, and appear mostly as phase II glucuronide, sulfate, and methyl metabolites [185]. Based on limited animal studies, (-)-epicatechin metabolites seem to reach the brain of rodents at levels that might be physiologically effective [186]. Some conjugated forms of quercetin can also accumulate in the brain after oral administration, while aglycone quercetin is scarcely distributed in the CNS $[187,188]$.

Anthocyanins are the glycosides of 2-phenyl-benzopyrylium or flavylium salts, which have different hydroxy or methoxy groups. As major anthocyanin flavonoids, glycosides of cyanidin (particularly cyanidin-3-glucoside) are primarily present in most of the herbs [189]. Several in vitro/in vivo studies have shown the pharmacokinetic characteristics of anthocyanins and their passage through the BBB. Studies showing that anthocyanins and some of their metabolites are able to cross the BBB have recently been reviewed in detail by Manolescu et al. [190]. Cyanidin-3-glucoside has been shown as the most absorbed anthocyanin through the jejunum and ileum in rats followed by cyanidin-3-galactoside and cyanidin-3-rutinoside [191]. Anthocyanins are hydrolyzed to anthocyanidins through removal of the 3-O-glycosidic part by colon microbiota. Phase I and II reactions mainly occur in the small intestine and liver, and the anthocyanidins become glucuronide, sul- phate, or methyl derivatives. Anthocyanins metabolites are eliminated from the body by urine, bile, feces, and breath $[192,193]$.

\section{Conclusion}

The genus of Pistacia has demonstrated various activities such as antioxidant, anti-inflammatory activities, and inhibitory effects on the progression of neurodegeneration together with promoting neuronal growth. These mentioned bioactivities along with their modulatory roles in functions of neurotransmitters, and modulation of signaling pathways as well as maintenance of BBB integrity support promising action of the plants for development in neuroprotective approaches. Phenolic compounds and terpenes as the two main groups of phytochemicals have been identified in different species of the genus Pistacia. $\alpha$-Pinene, $\beta$-caryophyllene, and oleanolic, ursolic, and masticadienonic acids as well as gallic acid, quercetin, and catechins are among the most abundant compounds in Pistacia. They demonstrated notable neuroprotective effects against different neurotoxic agents. The characteristic feature of these species is the production of remarkable essential oils from different parts of plants as well as large quantities of oleore$\sin$. The obtained oleoresins are rich in terpenes, which have been supported by substantial evidence for their antioxidant, anti-inflammatory, and neuroprotective effects.

In this study, we reviewed the neuroprotective efficacy of the genus Pistacia and the related molecular mechanisms of these herbs in various in vitro and in vivo models. The supporting scientific evidence shows that the Pistacia genus might be considered a potential source as a therapeutic agent for the treatment of NDs due to the multitargeted mechanism of action. However, further detailed investigations are essential to assess their safety, efficacy, bioavailability, and probable molecular evaluation experiments.

\section{Conflict of Interest}

The authors declare that they have no conflict of interest.

References

[1] Parvez MK. Natural or plant products for the treatment of neurological disorders: current knowledge. Curr Drug Metab 2018; 19: 424-428

[2] Kumar GP, Khanum F. Neuroprotective potential of phytochemicals. Pharmacogn Rev 2012; 6: 81-90

[3] Elufioye TO, Berida TI, Habtemariam S. Plants-derived neuroprotective agents: cutting the cycle of cell death through multiple mechanisms. Evid Based Complement Alternat Med 2017; 2017: 3574012

[4] Dugger BN, Dickson DW. Pathology of neurodegenerative diseases. Cold Spring Harb Perspect Biol 2017; 9: a028035

[5] Chen X, Pan W. The treatment strategies for neurodegenerative diseases by integrative medicine. Integr Med Int 2014; 1: 223-225

[6] Kumar GP, Anilakumar K, Naveen S. Phytochemicals having neuroprotective properties from dietary sources and medicinal herbs. Pharmacogn J 2015; 7: 1-17

[7] Iriti M, Vitalini S, Fico G, Faoro F. Neuroprotective herbs and foods from different traditional medicines and diets. Molecules 2010; 15: 35173555

[8] Bagli E, Goussia A, Moschos MM, Agnantis N, Kitsos G. Natural compounds and neuroprotection: mechanisms of action and novel delivery systems. In Vivo 2016; 30: 535-547 
[9] Rauf A, Patel S, Uddin G, Siddiqui BS, Ahmad B, Muhammad N, Mabkhot YN, Hadda TB. Phytochemical, ethnomedicinal uses and pharmacological profile of genus Pistacia. Biomed Pharmacother 2017; 86: 393-404

[10] Al-Saghir MG, Porter DM. Stomatal distribution in Pistacia sp.(Anacardiaceae). Int J Bot 2005; 1: 183-187

[11] Dimas KS, Pantazis P, Ramanujam R. Chios mastic gum: a plant-produced resin exhibiting numerous diverse pharmaceutical and biomedical properties. In Vivo 2012; 26: 777-785

[12] Bouasla A, Bouasla I. Ethnobotanical survey of medicinal plants in northeastern of Algeria. Phytomedicine 2017; 36: 68-81

[13] Zargaran A, Zarshenas MM, Karimi A, Yarmohammadi H, BorhaniHaghighi A. Management of stroke as described by Ibn Sina (Avicenna) in the Canon of Medicine. Int J Cardiol 2013; 169: 233-237

[14] Scherrer AM, Motti R, Weckerle CS. Traditional plant use in the areas of Monte Vesole and Ascea, Cilento National Park (Campania, Southern Italy). J Ethnopharmacol 2005; 97: 129-143

[15] Palmese MT, Uncini Manganelli RE, Tomei PE. An ethno-pharmacobotanical survey in the Sarrabus district (south-east Sardinia). Fitoterapia 2001; 72: 619-643

[16] Trabelsi H, Cherif OA, Sakouhi F, Villeneuve P, Renaud J, Barouh N, Boukhchina S, Mayer P. Total lipid content, fatty acids and 4-desmethylsterols accumulation in developing fruit of Pistacia lentiscus L. growing wild in Tunisia. Food Chem 2012; 131: 434-440

[17] Memariani Z, Sharifzadeh M, Bozorgi M, Hajimahmoodi M, Farzaei MH, Gholami M, Siavoshi F, Saniee P. Protective effect of essential oil of Pistacia atlantica Desf. on peptic ulcer: role of alpha-pinene. J Tradit Chin Med 2017; 37: 57-63

[18] Khorasani MA. Makhzan al Advieh (The Storehouse of Medicaments). Research Institute for Islamic and Complementary Medicine, Iran University of Medical Sciences. Tehran, Iran: Bavardaran Press (In Persian); 2001

[19] Gholami M, Ghasemi-Niri SF, Maqbool F, Baeeri M, Memariani Z, Pousti I, Abdollahi M. Experimental and Pathalogical study of Pistacia atlantica, butyrate, Lactobacillus casei and their combination on rat ulcerative colitis model. Pathol Res Pract 2016; 212: 500-508

[20] Ahmed HM. Traditional uses of Kurdish medicinal plant Pistacia atlantica subsp. kurdica Zohary in Ranya, Southern Kurdistan. Genet Resour Crop Evol 2017; 64: 1473-1484

[21] Saber-Tehrani M, Givianrad M, Aberoomand-Azar P, Waqif-Husain S, Jafari Mohammadi S. Chemical composition of Iran's Pistacia atlantica cold-pressed oil. J Chem 2012; 2013: 126106

[22] Bozorgi M, Memariani Z, Mobli M, Salehi Surmaghi MH, Shams-Ardekani MR, Rahimi R. Five Pistacia species ( $P$. vera, P. atlantica, P. terebinthus, $P$. khinjuk, and $P$. lentiscus): a review of their traditional uses, phytochemistry, and pharmacology. ScientificWorldJournal 2013; 2013: 219815

[23] Al-Saghir M. Evolutionary history of the genus Pistacia (Anacardiaceae). Int J Botany 2009; 5: 255-257

[24] Orhan I, Kupeli E, Aslan M, Kartal M, Yesilada E. Bioassay-guided evaluation of anti-inflammatory and antinociceptive activities of pistachio, Pistacia vera L. J Ethnopharmacol 2006; 105: 235-240

[25] Lev E, Amar Z. Ethnopharmacological survey of traditional drugs sold in the Kingdom of Jordan. J Ethnopharmacol 2002; 82: 131-145

[26] Uddin G, Rauf A, Rehman T, Qaisar M. Phytochemical screening of Pistacia chinensis var. integerrima. Middle East J Sci Res 2011; 7: 707-711

[27] Shirole R, Shirole N, Saraf M. In vitro relaxant and spasmolytic effects of essential oil of Pistacia integerrima Stewart ex Brandis Galls. J Ethnopharmacol 2015; 168: 61-65

[28] Couladis M, Özcan M, Tzakou O, Akgül A. Comparative essential oil composition of various parts of the turpentine tree (Pistacia terebinthus $\mathrm{L}$ ) growing wild in Turkey. J Sci Food Agric 2003; 83: 136-138
[29] Topçu G, Ay M, Bilici A, Sarıkürkcü C, Öztürk M, Ulubelen A. A new flavone from antioxidant extracts of Pistacia terebinthus. Food Chem 2007; 103: 816-822

[30] Cakilcioglu U, Khatun S, Turkoglu I, Hayta S. Ethnopharmacological survey of medicinal plants in Maden (Elazig-Turkey). J Ethnopharmacol 2011; 137: 469-486

[31] Golchin L, Shabani M, Harandi S, Razavinasab M. Pistachio supplementation attenuates motor and cognition impairments induced by cisplatin or vincristine in rats. Adv Biomed Res 2015; 4: 92

[32] Pak-Hashemi M, Hassanipour M, Mohammadinasab M, Kaeidi A, Shamsizadeh A, Hakimizadeh E, Allahtavakoli M, Fatemi I. Study the effects of Pistacia vera seed (pistachio) oil on working memory and spatial learning and memory. PHJ 2018; doi: doi:10.22123/PHJ.2018.146958.1016

[33] Salari E, Baloochi M, Shamsizadeh A, Ayoobi F, Allahtavakoli M, Taghavi Y, Ravari A. Effect of the hydroalcoholic extract of pistachio on avoidance learning in male Wistar rats. JOHE 2014; 3: 180-187

[34] Jazayeri SB, Amanlou A, Ghanadian N, Pasalar P, Amanlou M. A preliminary investigation of anticholinesterase activity of some Iranian medicinal plants commonly used in traditional medicine. Daru 2014; 22: 17

[35] Gholamhoseinian A, Moradi M, Sharifi-Far F. Screening the methanol extracts of some Iranian plants for acetylcholinesterase inhibitory activity. Res Pharm Sci 2009; 4: 105

[36] Rostampour M, Hadipour E, Oryan S, Soltani B, Saadat F. Anxiolytic-like effect of hydroalcoholic extract of ripe pistachio hulls in adult female Wistar rats and its possible mechanisms. Res Pharm Sci 2016; 11: 454460

[37] Kim JK, Shin EC, Kim CR, Park GG, Choi S], Cho HY, Shin DH. Composition of fatty acids in commercially available tree nuts and their relationship with protective effects against oxidative stress-induced neurotoxicity. Food Sci Biotechnol 2013; 22: 1097-1104

[38] Mansouri SMT, Naghizadeh B, Hosseinzadeh H. The effect of Pistacia vera L. gum extract on oxidative damage during experimental cerebral ischemia-reperfusion in rats. Iran Biomed J 2005; 9: 181-185

[39] Mansouri S, Naghizadeh B, Hosseinzadeh H. Evaluation the neuroprotective effect of Pistacia vera $\mathrm{L}$. gum extract against cerebral ischemia-reperfusion model of rats. Toxicol Lett 2011; 205: S297

[40] Ziaee TT, Hosseinzadeh H. Muscle relaxant, hypnotic and anti-anxiety effects of Pistacia vera gum hydroalcoholic extract in mice. J Med Plant 2010; 9: 96-105, 207

[41] Fatehi F, Fatemi I, Shamsizadeh A, Hakimizadeh E, Bazmandegan G, Khajehasani F, Rahmani M. The effect of hydroalcoholic extract of Pistacia vera on pentylenetetrazole-induced kindling in rat. Res J Pharmacogn 2017; 4: 45-51

[42] Ammari M, Othman H, Hajri A, Sakly M, Abdelmelek H. Pistacia lentiscus oil attenuates memory dysfunction and decreases levels of biomarkers of oxidative stress induced by lipopolysaccharide in rats. Brain Res Bull 2018; 140: 140-147

[43] Benamar H, Rached W, Derdour A, Marouf A. Screening of Algerian medicinal plants for acetylcholinesterase inhibitory activity. J Biol Sci 2010; 10: $1-9$

[44] Roghani M. A study on inhibitory effect of ethanolic extract of the Pistacia lentiscus on acetylcholinesterase activity. JBCP 2017; 5: 39-44

[45] Adhami HR, Farsam H, Krenn L. Screening of medicinal plants from Iranian traditional medicine for acetylcholinesterase inhibition. Phytother Res 2011; 25: 1148-1152

[46] Dhouafli Z, Rigacci S, Leri M, Bucciantini M, Mahjoub B, Tounsi MS, Wannes WA, Stefani M, Hayouni EA. Screening for amyloid- $\beta$ aggregation inhibitor and neuronal toxicity of eight Tunisian medicinal plants. Ind Crop Prod 2018; 111: 823-833

[47] Pacifico S, Piccolella S, Marciano S, Galasso S, Nocera P, Piscopo V, Fiorentino A, Monaco P. LC-MS/MS profiling of a mastic leaf phenol enriched extract and its effects on $\mathrm{H} 2 \mathrm{O} 2$ and Abeta(25-35) oxidative injury in SK-B-NE(C)-2 cells. J Agric Food Chem 2014; 62: 11957-11966 
[48] Quartu M, Serra MP, Boi M, Pillolla G, Melis T, Poddighe L, Del Fiacco M, Falconieri D, Carta G, Murru E, Cordeddu L, Piras A, Collu M, Banni S. Effect of acute administration of Pistacia lentiscus L. essential oil on rat cerebral cortex following transient bilateral common carotid artery occlusion. Lipids Health Dis 2012; 11: 8

[49] Benamar H, Marouf A, Bennaceur M. Phytochemical composition, antioxidant and acetylcholinesterase inhibitory activities of aqueous extract and fractions of Pistacia atlantica subsp. atlantica from Algeria. J Herbs Spices Med Plants 2018; 24: 229-244

[50] Peksel A, Arisan I, Yanardag R. Radical scavenging and anti-acetylcholinesterase activities of aqueous extract of wild pistachio (Pistacia atlantica Desf.) leaves. Food Sci Biotechnol 2013; 22: 515-522

[51] Peksel A, Arisan-Atac I, Yanardag R. Evaluation of antioxidant and antiacetylcholinesterase activities of the extracts of Pistacia atlantica desf. leaves. J Food Biochem 2010; 34: 451-476

[52] Labed-Zouad I, Ferhat M, Öztürk M, Abaza I, Nadeem S, Kabouche A, Kabouche Z. Essential Oils Composition, Anticholinesterase and Antioxidant Activities of Pistacia atlantica Desf. Rec Nat Prod 2017; 11: 411-415

[53] Rashidi S, Askari N, Abbasnejad M. Anxiolytic-like effect of Pistacia atlantica fruit in intact and gonadectomized rats subjected to chronic stress. JOHE 2014; 3: 152-159

[54] Mohammadzadeh M, Babaeifar F, Babaei F. Combination thrapy of hydroalcoholic extract of Pistacia atlantica kurdica and fluvoxamine on spatial memory of immobilization rat. J Gorgan Univ Med Sci 2017; 19: 2431

[55] Fewell W, van de Venter M, Marouf A, Houari B, Koekemoer T. An assessment of the in vitro neuroprotective properties of selected Algerian and South African medicinal plant extracts. Planta Med 2014; 80: P2B43

[56] Ansari SH, Qadry JS, Ali M. Essential oils of Pistacia integerrima galls and their effect on the central nervous system. Int J pharmacogn 1993; 31 : 89-95

[57] Zahoor M, Zafar R, Rahman NU. Isolation and identification of phenolic antioxidants from Pistacia integerrima gall and their anticholine esterase activities. Heliyon 2018; 4: e01007

[58] Jain PD, Tambe RM, Sancheti JS, Nahire MS, Bhardwaj AK, Sathaye S. Screening of Pistacia integerrima extracts for their anticonvulsant activity in acute zebrafish and rodent models of epilepsy. Int J Nutr Pharmacol Neurol Dis 2015; 5: 56

[59] Orhan IE, Senol FS, Gulpinar AR, Sekeroglu N, Kartal M, Sener B. Neuroprotective potential of some terebinth coffee brands and the unprocessed fruits of Pistacia terebinthus L. and their fatty and essential oil analyses. Food Chem 2012; 130: 882-888

[60] Prakash D, Gupta C. Phytopharmaceutical applications of nutraceutical and functional foods. In: Information Resources Management Association. Complementary and alternative medicine: breakthroughs in research and practice. Hershey, Pennsylvania: IGI Global; 2019: 182-204

[61] Polo-Hernandez E, Tello V, Arroyo AA, Domínquez-Prieto M, de Castro F, Tabernero A, Medina JM. Oleic acid synthesized by stearoyl-CoA desaturase (SCD-1) in the lateral periventricular zone of the developing rat brain mediates neuronal growth, migration and the arrangement of prospective synapses. Brain Res 2014; 1570: 13-25

[62] Gao H, Yan P, Zhang S, Nie S, Huang F, Han H, Deng Q, Huang Q, Yang W, $\mathrm{Wu} \mathrm{H}$. Chronic alpha-linolenic acid treatment alleviates age-associated neuropathology: roles of PERK/eIF2 $\alpha$ signaling pathway. Brain Behav Immun 2016; 57: 314-325

[63] Shirooie S, Nabavi SF, Dehpour AR, Belwal T, Habtemariam S, Argüelles S, Sureda A, Daglia M, Tomczyk M, Sobarzo-Sanchez E, Xu S, Nabavi SM. Targeting mTORs by omega- 3 fatty acids: A possible novel therapeutic strategy for neurodegeneration? Pharmacol Res 2018; 135: 37-48

[64] Gorji N, Moeini R, Memariani Z. Almond, hazelnut and walnut, three nuts for neuroprotection in Alzheimer's disease: A neuropharmacological review of their bioactive constituents. Pharmacol Res 2018; 129: 115-127
[65] Pichersky E, Raguso RA. Why do plants produce so many terpenoid compounds? New Phytol 2018; 220: 692-702

[66] Yoram G, Inbar M. Distinct antimicrobial activities in aphid galls on Pistacia atlantica. Plant Signal Behav 2011; 6: 2008-2012

[67] Pinheiro M de A, Magalhães RM, Torres DM, Cavalcante RC, Mota FS, Oliveira Coelho EM, Moreira HP, Lima GC, Araújo PC, Cardoso JH, de Souza AN, Diniz LR. Gastroprotective effect of alpha-pinene and its correlation with antiulcerogenic activity of essential oils obtained from Hyptis species. Pharmacogn Mag 2015; 11: 123

[68] Yang H, Woo J, Pae AN, Um MY, Cho NC, Park KD, Yoon M, Kim J, Lee C], Cho S. $\alpha$-Pinene, a major constituent of pine tree oils, enhances non-rapid eye movement sleep in mice through GABAA-benzodiazepine receptors. Mol Pharmacol 2016; 90: 530-539

[69] Shekhany HKA, Ahmed HA. The study of chemical composition of gum in Pistacia atlantica in Erbil region. Zanco J Pure Appl Sci 2018; 30: 26-32

[70] Alma MH, Nitz S, Kollmannsberger H, Digrak M, Efe FT, Yilmaz N. Chemical composition and antimicrobial activity of the essential oils from the gum of Turkish pistachio (Pistacia vera L.). J Agric Food Chem 2004; 52: 3911-3914

[71] Porres-Martínez M, González-Burgos E, Carretero ME, Gómez-Serranillos MP. In vitro neuroprotective potential of the monoterpenes $\alpha$-pinene and 1, 8-cineole against $\mathrm{H} 2 \mathrm{O} 2$-induced oxidative stress in PC12 cells. Z Naturforsch C 2016; 71: 191-199

[72] Lee GY, Lee C, Park GH, Jang JH. Amelioration of scopolamine-induced learning and memory impairment by $\alpha$-pinene in C57BL/6 mice. Evid Based Complement Alternat Med 2017; 2017: 4926815

[73] Goudarzi S, Rafieirad M. Evaluating the effect of $\alpha$-pinene on motor activity, avoidance memory and lipid peroxidation in animal model of Parkinson disease in adult male rats. RJP 2017; 4: 53-63

[74] Kasuya H, Okada N, Kubohara M, Satou T, Masuo Y, Koike K. Expression of BDNF and TH mRNA in the brain following inhaled administration of $\alpha$ pinene. Phytother Res 2015; 29: 43-47

[75] Ueno H, Shimada A, Suemitsu S, Murakami S, Kitamura N, Wani K, Matsumoto Y, Okamoto M, Ishihara T. Attenuation effects of alphapinene inhalation on mice with dizocilpine-induced psychiatric-like behaviour. Evid Based Complement Alternat Med 2019; 2019: 2745453

[76] Sabogal-Guáqueta AM, Osorio E, Cardona-Gómez GP. Linalool reverses neuropathological and behavioral impairments in old triple transgenic Alzheimer's mice. Neuropharmacology 2016; 102: 111-120

[77] Mehri S, Meshki MA, Hosseinzadeh H. Linalool as a neuroprotective agent against acrylamide-induced neurotoxicity in Wistar rats. Drug Chem Toxicol 2015; 38: 162-166

[78] Park H, Seol GH, Ryu S, Choi IY. Neuroprotective effects of (-)-linalool against oxygen-glucose deprivation-induced neuronal injury. Arch Pharm Res 2016; 39: 555-564

[79] Barrera-Sandoval AM, Osorio E, Cardona-Gómez GP. Microglial-targeting induced by intranasal linalool during neurological protection postischemia. Eur ] Pharmacol 2019; 857: 172420

[80] Gertsch J, Leonti M, Raduner S, Racz I, Chen JZ, Xie XQ, Altmann KH, Karsak M, Zimmer A. Beta-caryophyllene is a dietary cannabinoid. P Natl Acad Sci 2008; 105: 9099-9104

[81] Machado KDC, Islam MT, Ali ES, Rouf R, Uddin SJ, Dev S, Shilpi JA, Shill MC, Reza HM, Das AK, Shaw S, Mubarak MS, Mishra SK, Melo-Cavalcante AAC. A systematic review on the neuroprotective perspectives of betacaryophyllene. Phytother Res 2018; 32: 2376-2388

[82] Lou J, Teng Z, Zhang L, Yang J, Ma L, Wang F, Tian X, An R, Yang M, Zhang $\mathrm{Q}$, Xu L, Dong Z. $\beta$-Caryophyllene/Hydroxypropyl- $\beta$-Cyclodextrin Inclusion Complex Improves Cognitive Deficits in Rats with Vascular Dementia through the Cannabinoid Receptor Type 2 -Mediated Pathway. Front Pharmacol 2017; 8: 2 
[83] Poddighe L, Carta G, Serra MP, Melis T, Boi M, Lisai S, Murru E, Muredda L, Collu M, Banni S. Acute administration of beta-caryophyllene prevents endocannabinoid system activation during transient common carotid artery occlusion and reperfusion. Lipids Health Dis 2018; 17: 23

[84] Cheng Y, Dong Z, Liu S. beta-Caryophyllene ameliorates the Alzheimerlike phenotype in APP/PS1 Mice through CB2 receptor activation and the PPARgamma pathway. Pharmacology 2014; 94: 1-12

[85] Assis LC, Straliotto MR, Engel D, Hort MA, Dutra RC, de Bem AF. betaCaryophyllene protects the C6 glioma cells against glutamate-induced excitotoxicity through the Nrf2 pathway. Neuroscience 2014; 279 : 220-231

[86] Askari VR, Shafiee-Nick R. Promising neuroprotective effects of betacaryophyllene against LPS-induced oligodendrocyte toxicity: A mechanistic study. Biochem Pharmacol 2019; 159: 154-171

[87] Youssef DA, El-Fayoumi HM, Mahmoud MF. Beta-caryophyllene alleviates diet-induced neurobehavioral changes in rats: The role of CB2 and PPARgamma receptors. Biomed Pharmacother 2019; 110: 145-154

[88] Viveros-Paredes JM, Gonzalez-Castaneda RE, Gertsch J, Chaparro-Huerta V, Lopez-Roa RI, Vazquez-Valls E, Beas-Zarate C, Camins-Espuny A, Flores-Soto ME. Neuroprotective effects of beta-caryophyllene against dopaminergic neuron injury in a murine model of Parkinson's disease induced by MPTP. Pharmaceuticals (Basel) 2017; 10: E60

[89] Ojha S, Javed H, Azimullah S, Haque ME. beta-Caryophyllene, a phytocannabinoid attenuates oxidative stress, neuroinflammation, glial activation, and salvages dopaminergic neurons in a rat model of Parkinson disease. Mol Cell Biochem 2016; 418: 59-70

[90] Chang HJ, Kim JM, Lee JC, Kim WK, Chun HS. Protective effect of betacaryophyllene, a natural bicyclic sesquiterpene, against cerebral ischemic injury. J Med Food 2013; 16: 471-480

[91] Yang M, Lv Y, Tian X, Lou J, An R, Zhang Q, Li M, Xu L, Dong Z. Neuroprotective effect of $\beta$-caryophyllene on cerebral ischemia-reperfusion injury via regulation of necroptotic neuronal death and inflammation: In Vivo and in Vitro. Front Neurosci 2017; 11: 583-583

[92] Lou J, Cao G, Li R, Liu J, Dong Z, Xu L. beta-caryophyllene attenuates focal cerebral ischemia-reperfusion injury by $\mathrm{Nrf2/HO}-1$ pathway in rats. Neurochem Res 2016; 41: 1291-1304

[93] Chang HJ, Kim HJ, Chun HS. Quantitative structure-activity relationship (QSAR) for neuroprotective activity of terpenoids. Life Sci 2007; 80: 835-841

[94] Amhamdi H, Aouinti F, Wathelet JP, Elbachiri A. Chemical composition of the essential oil of Pistacia lentiscus L. from Eastern Morocco. Rec Nat Prod 2009; 3: 90

[95] Mahmoudvand H, Kheirandish F, Ghasemi Kia M, Tavakoli Kareshk A, Yarahmadi M. Chemical composition, protoscolicidal effects and acute toxicity of Pistacia atlantica Desf. fruit extract. Nat Prod Res 2016; 30: 1208-1211

[96] Ciftci O, Oztanir MN, Cetin A. Neuroprotective effects of $\beta$-myrcene following global cerebral ischemia/reperfusion-mediated oxidative and neuronal damage in a C57BL/J6 mouse. Neurochem Res 2014; 39: 1717-1723

[97] Tang XP, Guo XH, Geng D, Weng LJ. d-Limonene protects PC12 cells against corticosterone-induced neurotoxicity by activating the AMPK pathway. Environ Toxicol Pharmacol 2019; 70: 103192

[98] Bigdeli Y, Asle-Rousta M, Rahnema M. Effects of limonene on chronic restraint stress-induced memory impairment and anxiety in male rats. Neurophysiology 2019; 51: 107-113

[99] Wang X, Li G, Shen W. Protective effects of D-Limonene against transient cerebral ischemia in stroke-prone spontaneously hypertensive rats. Exp Ther Med 2018; 15: 699-706
[100] Zhou W, Fukumoto S, Yokogoshi H. Components of lemon essential oil attenuate dementia induced by scopolamine. Nutr Neurosci 2009; 12: 57-64

[101] Ruszkowski P, Bobkiewicz-Kozlowska T. Natural triterpenoids and their derivatives with pharmacological activity against neurodegenerative disorders. Mini Rev Org Chem 2014; 11: 307-315

[102] Yoo KY, Park SY. Terpenoids as potential anti-Alzheimer's disease therapeutics. Molecules 2012; 17: 3524-3538

[103] Kaliora A, Mylona A, Chiou A, Petsios D, Andrikopoulos N. Detection and identification of simple phenolics in Pistacia lentiscus resin. J Liq Chromatogr Relat Technol 2004; 27: 289-300

[104] Noguera-Artiaga L, Pérez-López D, Burgos-Hernández A, Wojdyło A Carbonell-Barrachina ÁA. Phenolic and triterpenoid composition and inhibition of $\alpha$-amylase of pistachio kernels (Pistacia vera L.) as affected by rootstock and irrigation treatment. Food Chem 2018; 261: 240245

[105] Ayeleso T, Matumba M, Mukwevho E. Oleanolic acid and its derivatives: biological activities and therapeutic potential in chronic diseases. Molecules 2017; 22: 1915

[106] Martín R, Carvalho-Tavares J, Hernández M, Arnes M, Ruiz-Gutierrez V, Nieto ML. Beneficial actions of oleanolic acid in an experimental model of multiple sclerosis: a potential therapeutic role. Biochem Pharmacol 2010; 79: 198-208

[107] Han YW, Liu XJ, Zhao Y, Li XM. Role of Oleanolic acid in maintaining BBB integrity by targeting p38MAPK/VEGF/Src signaling pathway in rat model of subarachnoid hemorrhage. Eur J Pharmacol 2018; 839: $12-20$

[108] Martín R, Hernández M, Córdova C, Nieto ML. Natural triterpenes modulate immune-inflammatory markers of experimental autoimmune encephalomyelitis: therapeutic implications for multiple sclerosis. $\mathrm{Br}$ J Pharmacol 2012; 166: 1708-1723

[109] Mabandla MV, Nyoka M, Daniels WM. Early use of oleanolic acid provides protection against 6-hydroxydopamine induced dopamine neurodegeneration. Brain Res 2015; 1622: 64-71

[110] Msibi ZNP, Mabandla MV. Oleanolic acid mitigates 6-hydroxydopamine neurotoxicity by attenuating intracellular ROS in PC12 cells and striatal microglial activation in rat brains. Front Physiol 2019; 10: 1059

[111] Zhang SQ, Lin KL, Law CY, Liu B, Fu XQ, Tse WS, Wong SSM, Sze SCW, Yung KKL. Oleanolic acid enhances neural stem cell migration, proliferation, and differentiation in vitro by inhibiting GSK3 $\beta$ activity. Cell Death Dis 2018; 5: 48

[112] Caltana L, Rutolo D, Nieto ML, Brusco A. Further evidence for the neuroprotective role of oleanolic acid in a model of focal brain hypoxia in rats. Neurochem Int 2014; 79: 79-87

[113] Zhang L, Xia R, Jia J, Wang L, Li K, Li Y, Zhang J. Oleanolic acid protects against cognitive decline and neuroinflammation-mediated neurotoxicity by blocking secretory phospholipase A2 IIA-activated calcium signals. Mol Immunol 2018; 99: 95-103

[114] Cargnin ST, Gnoatto SB. Ursolic acid from apple pomace and traditional plants: A valuable triterpenoid with functional properties. Food Chem 2017; 220: 477-489

[115] Liang W, Zhao X, Feng J, Song F, Pan Y. Ursolic acid attenuates betaamyloid-induced memory impairment in mice. Arq Neuropsiquiatr 2016; 74: 482-488

[116] Heo HJ, Cho HY, Hong B, Kim HK, Heo TR, Kim EK, Kim SK, Kim CJ, Shin $\mathrm{DH}$. Ursolic acid of Origanum majorana L. reduces Abeta-induced oxidative injury. Mol Cells 2002; 13: 5-11

[117] Yoon JH, Youn K, Ho CT, Karwe MV, Jeong WS, Jun M. p-Coumaric Acid and Ursolic Acid from Corni fructus attenuated $\beta$-Amyloid $25-35$-Induced Toxicity through Regulation of the NF-kB Signaling Pathway in PC12 cells. J Agric Food Chem 2014; 62: 4911-4916 
[118] Hong SY, Jeong WS, Jun M. Protective effects of the key compounds isolated from Corni fructus against $\beta$-amyloid-induced neurotoxicity in PC12 cells. Molecules 2012; 17: 10831-10845

[119] Lu J, Zheng YL, Wu DM, Luo L, Sun DX, Shan Q. Ursolic acid ameliorates cognition deficits and attenuates oxidative damage in the brain of senescent mice induced by D-galactose. Biochem Pharmacol 2007; 74: 1078-1090

[120] Bahrami SA, Bakhtiari N. Ursolic acid regulates aging process through enhancing of metabolic sensor proteins level. Biomed Pharmacother 2016; 82: 8-14

[121] Loesche A, Köwitsch A, Lucas SD, Al-Halabi Z, Sippl W, Al-Harrasi A, Csuk R. Ursolic and oleanolic acid derivatives with cholinesterase inhibiting potential. Bioorg Chem 2019; 85: 23-32

[122] Rai SN, Yadav SK, Singh D, Singh SP. Ursolic acid attenuates oxidative stress in nigrostriatal tissue and improves neurobehavioral activity in MPTP-induced Parkinsonian mouse model. J Chem Neuroanat 2016; 71: 41-49

[123] Sahu S, Li R, Kadeyala PK, Liu S, Schachner M. The human natural killer1 (HNK-1) glycan mimetic ursolic acid promotes functional recovery after spinal cord injury in mouse. J Nutr Biochem 2018; 55: 219-228

[124] Lu J, Wu DM, Zheng YL, Hu B, Cheng W, Zhang ZF, Shan Q. Ursolic acid improves high fat diet-induced cognitive impairments by blocking endoplasmic reticulum stress and IkappaB kinase beta/nuclear factorkappaB-mediated inflammatory pathways in mice. Brain Behav Immun 2011; 25: 1658-1667

[125] Li L, Zhang X, Cui L, Wang L, Liu H, Ji H, Du Y. Ursolic acid promotes the neuroprotection by activating $\mathrm{Nrf2}$ pathway after cerebral ischemia in mice. Brain Res 2013; 1497: 32-39

[126] Ding $H$, Wang $H$, Zhu L, Wei W. Ursolic acid ameliorates early brain injury after experimental traumatic brain injury in mice by activating the Nrf2 pathway. Neurochem Res 2017; 42: 337-346

[127] Zhang T, Su J, Guo B, Zhu T, Wang K, Li X. Ursolic acid alleviates early brain injury after experimental subarachnoid hemorrhage by suppressing TLR4-mediated inflammatory pathway. Int Immunopharmacol 2014; 23: 585-591

[128] Wang Y, He Z, Deng S. Ursolic acid reduces the metalloprotease/antimetalloprotease imbalance in cerebral ischemia and reperfusion injury. Drug Des Devel Ther 2016; 10: 1663-1674

[129] Khan I, Karim N, Ahmad W, Abdelhalim A, Chebib M. GABA-A receptor modulation and anticonvulsant, anxiolytic, and antidepressant activities of constituents from Artemisia indica Linn. Evid Based Complement Alternat Med 2016; 2016: 1215393

[130] Jeon S], Park HJ, Gao Q, Pena I], Park S], Lee HE, Woo H, Kim HJ, Cheong $\mathrm{JH}$, Hong E, Ryu JH. Ursolic acid enhances pentobarbital-induced sleeping behaviors via GABAergic neurotransmission in mice. Eur ] Pharmacol 2015; 762: 443-448

[131] Rauf A, Uddin G, Khan A, Siddiqui BS, Arfan M, Dalvandi K, Hadda TB. Pistagremic acid, a novel $\beta$-secretase enzyme (BACE1) inhibitor from Pistacia integerrima Stewart. Nat Prod Res 2015; 29: 1735-1738

[132] Giner-Larza EM, Máñez S, Giner RM, Recio MC, Prieto JM, Cerdá-Nicolás M, Ríos J. Anti-inflammatory triterpenes from Pistacia terebinthus galls. Planta Med 2002; 68: 311-315

[133] Hazan Z, Adamsky K, Lucassen A, Levin LA. A First-in-Human Phase 1 Randomized Single and Multiple Ascending Dose Study of RPh201 in Healthy Volunteers. Clin Pharm Drug Dev, advance online publication 28 June 2019; doi: doi:10.1002/cpdd.720

[134] Rath EZ, Hazan Z, Adamsky K, Solomon A, Segal ZI, Levin LA. Randomized controlled phase 2a study of RPh201 in previous nonarteritic anterior ischemic optic neuropathy. Neuroophthalmol 2019; 39: 291-298

[135] Daglia M, Di Lorenzo A, Nabavi SF, Talas ZS, Nabavi SM. Polyphenols: well beyond the antioxidant capacity: gallic acid and related compounds as neuroprotective agents: you are what you eat! Curr Pharm Biotechnol 2014; 15: 362-372
[136] Shahrzad S, Bitsch I. Determination of gallic acid and its metabolites in human plasma and urine by high-performance liquid chromatography. J Chromatogr B Biomed Sci Appl 1998; 705: 87-95

[137] Yasuda T, Inaba A, Ohmori M, Endo T, Kubo S, Ohsawa K. Urinary metabolites of gallic acid in rats and their radical-scavenging effects on 1 , 1-diphenyl-2-picrylhydrazyl radical. J Nat Prod 2000; 63: 1444-1446

[138] Yu Z, Song F, jin YC, Zhang WM, Zhang Y, Liu EJ, Zhou D, Bi LL, Yang Q, Li H. Comparative pharmacokinetics of gallic acid after oral administration of gallic acid monohydrate in normal and isoproterenol-induced myocardial infarcted rats. Front Pharmacol 2018; 9: 328

[139] Lu Z, Nie G, Belton PS, Tang H, Zhao B. Structure-activity relationship analysis of antioxidant ability and neuroprotective effect of gallic acid derivatives. Neurochem Int 2006; 48: 263-274

[140] Szwajgier D, Borowiec K, Pustelniak K. The neuroprotective effects of phenolic acids: molecular mechanism of action. Nutrients 2017; 9: 477

[141] Kim MJ, Seong AR, Yoo JY, Jin CH, Lee YH, Kim YJ, Lee J, Jun W], Yoon HG. Gallic acid, a histone acetyltransferase inhibitor, suppresses $\beta$ amyloid neurotoxicity by inhibiting microglial-mediated neuroinflammation. Mol Nutr Food Res 2011; 55: 1798-1808

[142] Shimmyo Y, Kihara T, Akaike A, Niidome T, Sugimoto H. Epigallocatechin-3-gallate and curcumin suppress amyloid beta-induced beta-site APP cleaving enzyme-1 upregulation. Neuroreport 2008; 19: 13291333

[143] Reznichenko L, Amit T, Zheng H, Avramovich-Tirosh Y, Youdim M, Weinreb $\mathrm{O}$, Mandel S. Reduction of iron-regulated amyloid precursor protein and $\beta$-amyloid peptide by (-)-epigallocatechin-3-gallate in cell cultures: implications for iron chelation in Alzheimer's disease. J Neurochem 2006; 97: 527-536

[144] Mansouri MT, Farbood Y, Sameri M], Sarkaki A, Naghizadeh B, Rafeirad M. Neuroprotective effects of oral gallic acid against oxidative stress induced by 6-hydroxydopamine in rats. Food Chem 2013; 138: 10281033

[145] Mirshekar MA, Sarkaki A, Farbood Y, Naseri MKG, Badavi M, Mansouri MT, Haghparast A. Neuroprotective effects of gallic acid in a rat model of traumatic brain injury: behavioral, electrophysiological, and molecular studies. Iran J Basic Med Sci 2018; 21: 1056

[146] Maya S, Prakash T, Madhu K. Assessment of neuroprotective effects of Gallic acid against glutamate-induced neurotoxicity in primary rat cortex neuronal culture. Neurochem Int 2018; 121: 50-58

[147] Pervin M, Unno K, Ohishi T, Tanabe H, Miyoshi N, Nakamura Y. Beneficial Effects of Green Tea Catechins on Neurodegenerative Diseases. Molecules (Basel) 2018; 23: 1297

[148] Ribeiro GAC, da Rocha CQ, Veloso WB, Fernandes RN, da Silva IS, Tanaka AA. Determination of the catechin contents of bioactive plant extracts using disposable screen-printed carbon electrodes in a batch injection analysis (BIA) system. Microchem J 2019; 146: 1249-1254

[149] Bansal S, Vyas S, Bhattacharya S, Sharma M. Catechin prodrugs and analogs: a new array of chemical entities with improved pharmacological and pharmacokinetic properties. Nat Prod Rep 2013; 30: 14381454

[150] Farzaei MH, Bahramsoltani R, Abbasabadi Z, Braidy N, Nabavi SM. Role of green tea catechins in prevention of age-related cognitive decline: Pharmacological targets and clinical perspective. J Cell Physiol 2019; 234: $2447-2459$

[151] Farkhondeh T, Yazdi HS, Samarghandian S. The protective effects of green tea catechins in the management of neurodegenerative diseases: A review. Curr Drug Discov Technol 2019; 16: 57-65

[152] Cheruku SP, Ramalingayya GV, Chamallamudi MR, Biswas S, Nandakumar K, Nampoothiri M, Gourishetti K, Kumar N. Catechin ameliorates doxorubicin-induced neuronal cytotoxicity in in vitro and episodic memory deficit in in vivo in Wistar rats. Cytotechnology 2018; 70: 245-259 
[153] Jiang Z, Zhang J, Cai Y, Huang J, You L. Catechin attenuates traumatic brain injury-induced blood-brain barrier damage and improves longerterm neurological outcomes in rats. Exp Physiol 2017; 102: 12691277

[154] Ide K, Matsuoka N, Yamada H, Furushima D, Kawakami K. Effects of tea catechins on Alzheimer's disease: recent updates and perspectives. Molecules 2018; 23: E2357

[155] Baluchnejadmojarad T, Roghani M. Chronic epigallocatechin-3-gallate ameliorates learning and memory deficits in diabetic rats via modulation of nitric oxide and oxidative stress. Behav Brain Res 2011; 224: 305-310

[156] Biasibetti R, Tramontina AC, Costa AP, Dutra MF, Quincozes-Santos A, Nardin P, Bernardi CL, Wartchow KM, Lunardi PS, Gonçalves CA. Green tea (-) epigallocatechin-3-gallate reverses oxidative stress and reduces acetylcholinesterase activity in a streptozotocin-induced model of dementia. Behav Brain Res 2013; 236: 186-193

[157] Levites Y, Weinreb O, Maor G, Youdim MB, Mandel S. Green tea polyphenol (-)-epigallocatechin-3-gallate prevents $\mathrm{N}$-methyl-4-phenyl-1, 2, 3, 6-tetrahydropyridine-induced dopaminergic neurodegeneration. J Neurochem 2001; 78: 1073-1082

[158] Tarozzi A, Morroni F, Merlicco A, Bolondi C, Teti G, Falconi M, CantelliForti G, Hrelia P. Neuroprotective effects of cyanidin 3-O-glucopyranoside on amyloid beta (25-35) oligomer-induced toxicity. Neurosci Lett 2010; 473: 72-76

[159] Barreca D, Bellocco E, D’Onofrio G, Nabavi SF, Daglia M, Rastrelli L, Nabavi SM. Neuroprotective effects of quercetin: from chemistry to medicine. CNS Neurol Disord Drug Targets 2016; 15: 964-975

[160] Amanzadeh E, Esmaeili A, Rahgozar S, Nourbakhshnia M. Application of quercetin in neurological disorders: from nutrition to nanomedicine. Rev Neuroscience 2019; 30: 555-572

[161] Costa LG, Garrick JM, Roquè PJ, Pellacani C. Mechanisms of neuroprotection by quercetin: counteracting oxidative stress and more. Oxid Med Cell Longev 2016; 2016: 2986796

[162] Sabogal-Guáqueta AM, Muñoz-Manco JI, Ramírez-Pineda JR, LampreaRodriguez M, Osorio E, Cardona-Gómez GP. The flavonoid quercetin ameliorates Alzheimer's disease pathology and protects cognitive and emotional function in aged triple transgenic Alzheimer's disease model mice. Neuropharmacology 2015; 93: 134-145

[163] Abdalla FH, Schmatz R, Cardoso AM, Carvalho FB, Baldissarelli ], de Oliveira JS, Rosa MM, Nunes MAG, Rubin MA, da Cruz IB. Quercetin protects the impairment of memory and anxiogenic-like behavior in rats exposed to cadmium: Possible involvement of the acetylcholinesterase and $\mathrm{Na+}$, K+-ATPase activities. Physiol Behav 2014; 135: 152-167

[164] Ansari MA, Abdul HM, Joshi G, Opii WO, Butterfield DA. Protective effect of quercetin in primary neurons against $A \beta(1-42)$ : relevance to Alzheimer's disease. J Nutr Biochem 2009; 20: 269-275

[165] Farzaei MH, Tewari D, Momtaz S, Argüelles S, Nabavi SM. Targeting ERK signaling pathway by polyphenols as novel therapeutic strategy for neurodegeneration. Chem Toxicol 2018; 120: 183-195

[166] Tchantchou F, Lacor PN, Cao Z, Lao L, Hou Y, Cui C, Klein WL, Luo Y. Stimulation of neurogenesis and synaptogenesis by bilobalide and quercetin via common final pathway in hippocampal neurons. J Alzheimers Dis 2009; 18: 787-798

[167] Shahpiri Z, Bahramsoltani R, Farzaei MH, Farzaei F, Rahimi R. Phytochemicals as future drugs for Parkinson's disease: a comprehensive review. Rev Neuroscience 2016; 27: 651-668

[168] Singh A, Naidu PS, Kulkarni SK. Quercetin potentiates L-Dopa reversal of drug-induced catalepsy in rats: possible COMT/MAO inhibition. Pharmacology 2003; 68: 81-88

[169] Bournival ], Quessy P, Martinoli MG. Protective effects of resveratrol and quercetin against MPP+ -induced oxidative stress act by modulating markers of apoptotic death in dopaminergic neurons. Cell Mol Neurobiol 2009; 29: 1169-1180
[170] Karuppagounder S, Madathil S, Pandey M, Haobam R, Rajamma U, Mohanakumar K. Quercetin up-regulates mitochondrial complex-I activity to protect against programmed cell death in rotenone model of Parkinson's disease in rats. Neuroscience 2013; 236: 136-148

[171] Kale A, Pişkin Ö, Baş Y, Aydın BG, Can M, Elmas Ö, Büyükuysal Ç. Neuroprotective effects of Quercetin on radiation-induced brain injury in rats. J Radiat Res 2018; 59: 404-410

[172] Lapi D, Vagnani S, Pignataro G, Esposito E, Paterni M, Colantuoni A. Protective effects of quercetin on rat pial microvascular changes during transient bilateral common carotid artery occlusion and reperfusion. Front Physiol 2012; 3: 32

[173] Zaplatic E, Bule M, Shah SZA, Uddin MS, Niaz K. Molecular mechanisms underlying protective role of quercetin in attenuating Alzheimer's disease. Life Sci 2019; 224: 109-119

[174] J C Furtado NA, Pirson L, Edelberg H, M Miranda L, Loira-Pastoriza C, Preat V, Larondelle Y, André CM. Pentacyclic triterpene bioavailability: an overview of in vitro and in vivo studies. Molecules 2017; 22: 400

[175] Gangwal A. Neuropharmacological effects of triterpenoids. Phytopharmacol 2013; 4: 354-372

[176] Kohlert C, Van Rensen I, März R, Schindler G, Graefe E, Veit M. Bioavailability and pharmacokinetics of natural volatile terpenes in animals and humans. Planta Med 2000; 66: 495-505

[177] Satou T, Hayakawa M, Kasuya H, Masuo Y, Koike K. Mouse brain concentrations of $\alpha$-pinene, limonene, linalool, and 1, 8-cineole following inhalation. Flavour Fragr J 2017; 32: 36-39

[178] Santos PS, Oliveira TC, R Júnior LM, Figueiras A, Nunes LCC. $\beta$-caryophyllene delivery systems: enhancing the oral pharmacokinetic and stability. Curr Pharm Des 2018; 24: 3440-3453

[179] Sterk V, Büchele B, Simmet T. Effect of food intake on the bioavailability of boswellic acids from a herbal preparation in healthy volunteers. Planta Med 2004; 70: 1155-1160

[180] Jinhua W. Ursolic acid: Pharmacokinetics process in vitro and in vivo, a mini review. Arch Pharm 2019; 352: e1800222

[181] Figueira I, Garcia G, Pimpão RC, Terrasso A, Costa I, Almeida A, Tavares L, Pais T, Pinto P, Ventura M. Polyphenols journey through blood-brain barrier towards neuronal protection. Sci Rep 2017; 7: 11456

[182] Ferruzzi MG, Lobo JK, Janle EM, Cooper B, Simon JE, Wu QL, Welch C, Ho L, Weaver C, Pasinetti GM. Bioavailability of gallic acid and catechins from grape seed polyphenol extract is improved by repeated dosing in rats: implications for treatment in Alzheimer's disease. J Alzheimers Dis 2009; 18: 113-124

[183] Manach C, Williamson G, Morand C, Scalbert A, Rémésy C. Bioavailability and bioefficacy of polyphenols in humans. I. Review of 97 bioavailability studies. Am J Clin Nutr 2005; 81: 230S-242S

[184] Viskupičová J, Ondrejovič M, Šturdík E. Bioavailability and metabolism of flavonoids. J Food Nutr Res 2008; 4: 151-162

[185] Crozier A, Del Rio D, Clifford MN. Bioavailability of dietary flavonoids and phenolic compounds. Mol Aspects Med 2010; 31: 446-467

[186] Renaud J, Martinoli MG. Considerations for the use of polyphenols as therapies in neurodegenerative diseases. Int J Mol Sci 2019; 8: E1883

[187] Ishisaka A, Ichikawa S, Sakakibara H, Piskula MK, Nakamura T, Kato Y, Ito M, Miyamoto K, Tsuji A, Kawai Y. Accumulation of orally administered quercetin in brain tissue and its antioxidative effects in rats. Free Radic Biol Med 2011; 51: 1329-1336

[188] Dajas F, Abin-Carriquiry JA, Arredondo F, Blasina F, Echeverry C, Martí nez M, Rivera F, Vaamonde L. Quercetin in brain diseases: Potential and limits. Neurochem Int 2015; 89: 140-148

[189] Mazza G, Miniati E. Anthocyanins in fruits, vegetables, and grains. Boca Raton: CRC Press; 1993

[190] Manolescu BN, Oprea E, Mititelu M, Ruta LL, Farcasanu IC. Dietary anthocyanins and stroke: A review of pharmacokinetic and pharmacodynamic studies. Nutrient 2019; 11: 1479 
[191] Talavera S, Felgines C, Texier O, Besson C, Manach C, Lamaison JL, Remesy $C$. Anthocyanins are efficiently absorbed from the small intestine in rats. J Nutr 2004; 134: 2275-2279

[192] Kalt W, Liu Y, McDonald JE, Vinqvist-Tymchuk MR, Fillmore SA. Anthocyanin metabolites are abundant and persistent in human urine. J Agric Food Chem 2014; 62: 3926-3934

[193] Czank C, Cassidy A, Zhang Q, Morrison DJ, Preston T, Kroon PA, Botting NP, Kay CD. Human metabolism and elimination of the anthocyanin, cyanidin-3-glucoside: a 13C-tracer study. Am J Clin Nutr 2013; 97: 995-1003

[194] Hosseinzadeh H, Behravan E, Soleimani MM. Antinociceptive and antiinflammatory effects of Pistacia vera leaf extract in mice. Iran J Pharm Res 2011; 10: 821

[195] Hajjaj G, Chakour R, Bahlouli A, Tajani M, Cherrah Y, Zellou A. Evaluation of CNS activity and anti-inflammatory effect of Pistacia atlantica desf. essential oil from Morocco. Pharm Chem J 2018; 5: 86-94

[196] Shirole RL, Shirole NL, Saraf MN. In vitro relaxant and spasmolytic effects of essential oil of Pistacia integerrima Stewart ex Brandis Galls. J Ethnopharmacol 2015; 168: 61-65

[197] Türkoğlu S, Çelik S, Keser S, Türkoğlu I, Yilmaz Ö. The effect of Pistacia terebinthus extract on lipid peroxidation, glutathione, protein, and some enzyme activities in tissues of rats undergoing oxidative stress. Turk J Zool 2017; 41: 82-88
[198] Satou T, Kasuya H, Maeda K, Koike K. Daily inhalation of $\alpha$-pinene in mice: effects on behavior and organ accumulation. Phytother Res 2014; 28: 1284-1287

[199] El Alaoui C, Chemin J, Fechtali T, Lory P. Modulation of T-type Ca2+ channels by Lavender and Rosemary extracts. PLoS One 2017; 12: e0186864

[200] Askari VR, Shafiee-Nick R. Promising neuroprotective effects of $\beta$ caryophyllene against LPS-induced oligodendrocyte toxicity: A mechanistic study. Biochem Pharmacol 2019; 159: 154-171

[201] Ojha S, Javed H, Azimullah S, Haque ME. $\beta$-Caryophyllene, a phytocannabinoid attenuates oxidative stress, neuroinflammation, glial activation, and salvages dopaminergic neurons in a rat model of Parkinson disease. Mol Cell Biochem 2016; 418: 59-70

[202] Liu H, Song Z, Liao D, Zhang T, Liu F, Zhuang K, Luo K, Yang L. Neuroprotective effects of trans-caryophyllene against kainic acid induced seizure activity and oxidative stress in mice. Neurochem Res 2015; 40: $118-123$

[203] de Oliveira CC, de Oliveira CV, Grigoletto J, Ribeiro LR, Funck VR, Grauncke ACB, de Souza TL, Souto NS, Furian AF, Menezes IRA. Anticonvulsant activity of $\beta$-caryophyllene against pentylenetetrazol-induced seizures. Epilepsy Behav 2016; 56: 26-31

[204] Lv C, Hong T, Yang Z, Zhang Y, Wang L, Dong M, Zhao ], Mu J, Meng Y. Effect of quercetin in the 1-methyl-4-phenyl-1, 2, 3, 6-tetrahydropyridine-induced mouse model of Parkinson's disease. Evid Based Complement Alternat Med 2012; 2012: 928643 